Prepared in cooperation with Mid-Columbia Fisheries Enhancement Group

\title{
Juvenile Salmonid Monitoring in the White Salmon River, Washington, Post-Condit Dam Removal, 2016
}

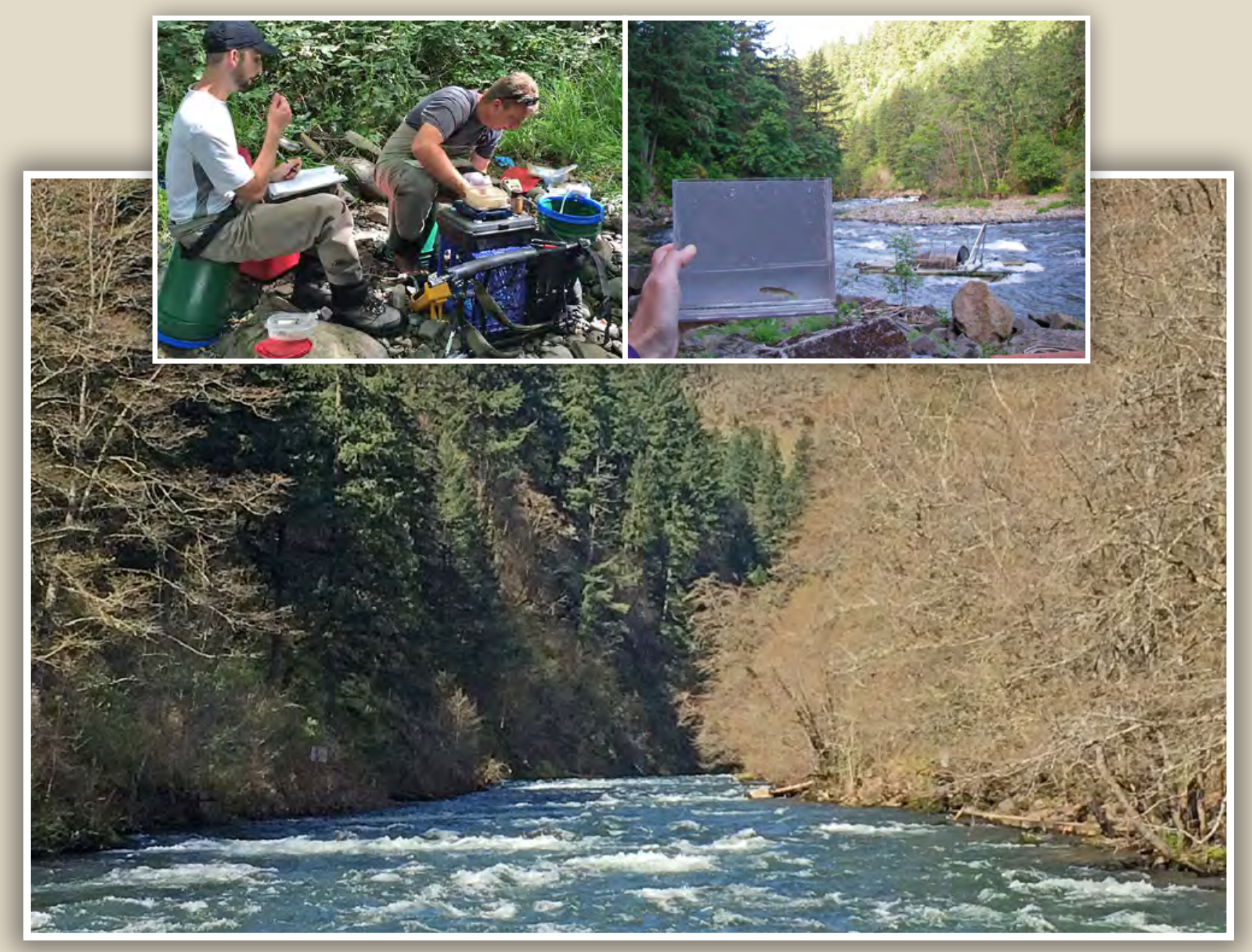

Open-File Report 2017-1070

U.S. Department of the Interior

U.S. Geological Survey 
Cover: Photograph showing White Salmon River, Washington, date.

Photograph by Jill Hardiman, U.S. Geological Survey, March 25, 2016.

Right Inset: Photograph showing Juvenile coho salmon and the rotary screw trap at river kilometer 2.3 of the White Salmon River, Washington. Photograph by Margaret Neuman, Mid-Columbia

Fisheries Enhancement Group, March 25, 2016.

Left Inset: Photograph showing scientists collecting data from fish in Rattlesnake Creek, Washington. Photograph by Jill Hardiman, U.S. Geological Survey, July 28, 2016. 


\section{Juvenile Salmonid Monitoring in the White Salmon River, Washington, Post-Condit Dam Removal, 2016}

By lan G. Jezorek and Jill M. Hardiman

Prepared in cooperation with Mid-Columbia Fisheries Enhancement Group

Open File Report 2017-1070

U.S. Department of the Interior

U.S. Geological Survey 


\section{U.S. Department of the Interior \\ RYAN K. ZINKE, Secretary}

\section{U.S. Geological Survey \\ William H. Werkheiser, Acting Director}

U.S. Geological Survey, Reston, Virginia: 2017

For more information on the USGS-the Federal source for science about the Earth, its natural and living resources, natural hazards, and the environment-visit https://www.usgs.gov/ or call 1-888-ASK-USGS (1-888-275-8747).

For an overview of USGS information products, including maps, imagery, and publications, visit https://store.usgs.gov.

Any use of trade, firm, or product names is for descriptive purposes only and does not imply endorsement by the U.S. Government.

Although this information product, for the most part, is in the public domain, it also may contain copyrighted materials as noted in the text. Permission to reproduce copyrighted items must be secured from the copyright owner.

Suggested citation: Jezorek, I.G., and Hardiman, J.M., 2017, Juvenile salmonid monitoring in the White Salmon River, Washington, post-Condit Dam removal, 2016: U.S. Geological Survey Open-File Report 2017-1070, 34 p., https://doi.org/10.3133/ofr20171070.

ISSN 2331-1258 (online) 


\section{Contents}

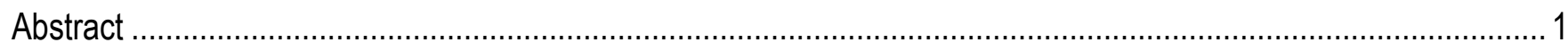

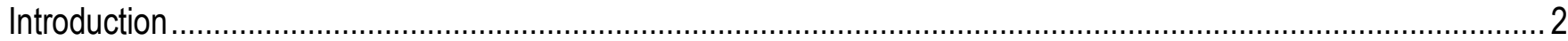

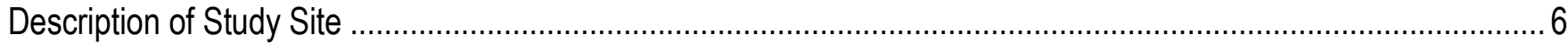

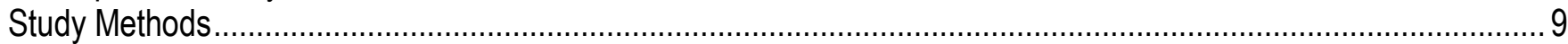

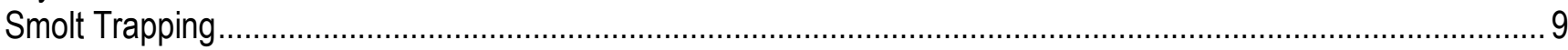

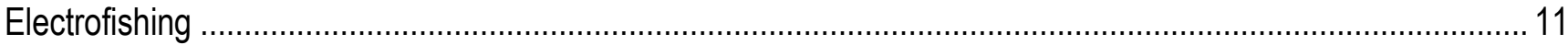

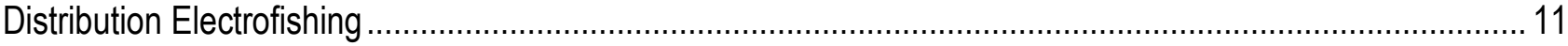





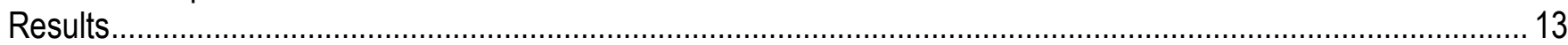

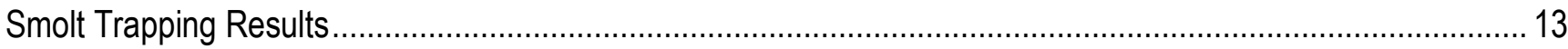

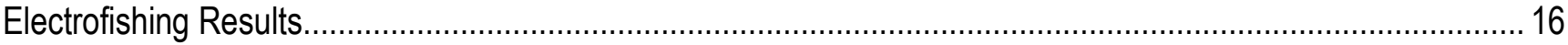

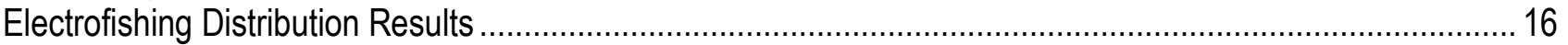

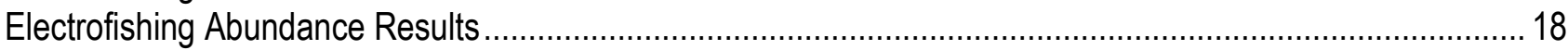

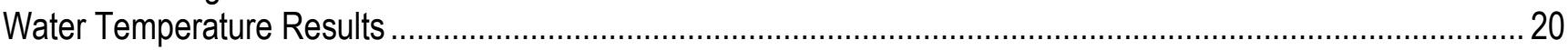

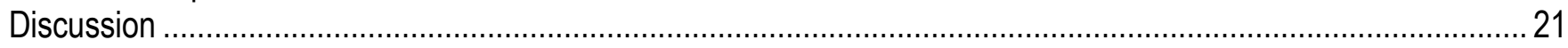

Acknowledgments

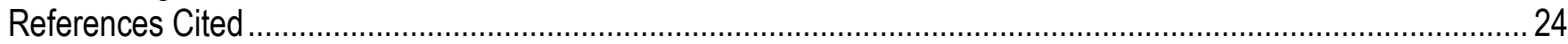

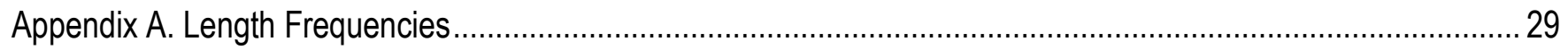

\section{Figures}

Figure 1. Map showing the White Salmon River watershed accessible to anadromous salmonids and locations of rotary screw trapping and electrofishing surveys, Washington, 2016

Figure 2. Graphs showing daily catch of steelhead (Oncorhynchus mykiss) parr (upper graph) and smolts (lower graph) in the screw trap at river kilometer 2.3, White Salmon River, Washington, March 24-May 28, 2016.

Figure 3. Graph showing daily catch of coho salmon (Oncorhynchus kisutch) smolts in the screw trap at river kilometer 2.3, White Salmon River, Washington, March 24-May 28, 2016

Figure 4. Graph showing abundance estimates (fish per meter) of steelhead/rainbow trout (sth/rbt)

(Oncorhynchus mykiss) at a site in the lower kilometer of Rattlesnake Creek, Washington

Figure 5. Graph showing abundance estimates (fish per meter) of steelhead/rainbow trout (sth/rbt) (Oncorhynchus mykiss) and coho salmon (O. kisutch) at a sample site at river kilometer 2.0, Buck Creek, Washington 


\section{Tables}

Table 1. Latitude and longitude (decimal degrees) of fish sampling and water temperature monitoring locations, White Salmon River watershed, Washington, 2016

Table 2. Number of steelhead (Oncorhynchus mykiss), Chinook salmon (O. tshawytscha), and coho salmon (O. kisutch), by life-stage, captured, tagged with Passive Integrated Transponder (PIT) tags, and sampled for genetic material at the smolt trap at river kilometer 2.3, White Salmon River, Washington, March 24-May 28, 2016 13

Table 3. Estimates of steelhead (Oncorhynchus mykiss) smolt and coho salmon (O. kisutch) smolt passage at the smolt trap at river kilometer 2.3, White Salmon River, Washington, March 24-May 28, 2016.

Table 4. Presence and absence of steelhead/rainbow trout (Oncorhynchus mykiss), Chinook salmon ( 0 . tshawytscha), coho salmon ( 0 . kisutch), and cutthroat trout (O. clarki clarki) at electrofishing sites in the White Salmon River subbasin, Washington, summer 2016

Table 5. Number of juvenile salmonids encountered and tagged with Passive Integrated Transponder (PIT) tags, and from which a tissue sample was collected for genetic analysis during electrofishing surveys in the White Salmon River watershed, Washington, 2016.

Table 6. Population estimates and standard error (SE), abundance (fish per meter), and density (fish per meter squared) of steelhead/rainbow trout (Oncorhynchus mykiss) and coho salmon (O. kisutch) at abundance electrofishing sites in Buck and Rattlesnake Creeks, July 2016

Table 7. Minimum, mean, and maximum water temperature, and number of days when water temperature met or exceeded $16{ }^{\circ} \mathrm{C}$ at five sites in the White Salmon River watershed, Washington, June-October 2016

\section{Conversion Factors}

International System of Units to U.S. customary units

\begin{tabular}{lcl}
\hline \multicolumn{1}{c}{ Multiply } & By & To obtain \\
\hline centimeter $(\mathrm{cm})$ & Length & \\
millimeter $(\mathrm{mm})$ & 0.3937 & inch (in.) \\
meter $(\mathrm{m})$ & 0.03937 & inch (in.) \\
kilometer $(\mathrm{km})$ & 3.281 & foot $(\mathrm{ft})$ \\
kilometer $(\mathrm{km})$ & 0.6214 & mile $(\mathrm{mi})$ \\
meter $(\mathrm{m})$ & 0.5400 & mile, nautical (nmi) \\
\hline & 1.094 & yard (yd) \\
\hline square meter $\left(\mathrm{m}^{2}\right)$ & Area & \\
square kilometer $\left(\mathrm{km}^{2}\right)$ & 0.0002471 & acre \\
square meter $\left(\mathrm{m}^{2}\right)$ & 247.1 & acre \\
square kilometer $\left(\mathrm{km}^{2}\right)$ & 10.76 & square foot $\left(\mathrm{ft}^{2}\right)$ \\
\hline & 0.3861 & square mile $\left(\mathrm{mi}^{2}\right)$ \\
\hline cubic meter $\left(\mathrm{m}^{3}\right)$ & Volume & \\
cubic meter $\left(\mathrm{m}^{3}\right)$ & 6.290 & barrel $(\mathrm{petroleum}, 1 \mathrm{barrel}=42 \mathrm{gal})$ \\
cubic meter $\left(\mathrm{m}^{3}\right)$ & 264.2 & gallon $(\mathrm{gal})$ \\
cubic meter $\left(\mathrm{m}^{3}\right)$ & 35.31 & cubic foot $\left(\mathrm{ft}^{3}\right)$ \\
cubic meter $\left(\mathrm{m}^{3}\right)$ & 1.308 & cubic yard $\left(\mathrm{yd}^{3}\right)$ \\
\hline & 0.0008107 & acre-foot $(\mathrm{acre}-\mathrm{ft})$ \\
\hline cubic meter per second $\left(\mathrm{m}^{3} / \mathrm{s}\right)$ & Flow rate & \\
cubic meter per second $\left(\mathrm{m}^{3} / \mathrm{s}\right)$ & 70.07 & acre-foot per day $(\mathrm{acre}-\mathrm{ft} / \mathrm{d})$ \\
cubic meter per second $\left(\mathrm{m}^{3} / \mathrm{s}\right)$ & 35.31 & cubic foot per second $\left(\mathrm{ft}^{3} / \mathrm{s}\right)$ \\
\hline
\end{tabular}

Temperature in degrees Celsius $\left({ }^{\circ} \mathrm{C}\right)$ may be converted to degrees Fahrenheit $\left({ }^{\circ} \mathrm{F}\right)$ as:

$$
{ }^{\circ} \mathrm{F}=\left(1.8 \times{ }^{\circ} \mathrm{C}\right)+32 .
$$




\title{
Juvenile Salmonid Monitoring in the White Salmon River, Washington, Post-Condit Dam Removal, 2016
}

By lan G. Jezorek and Jill M. Hardiman

\begin{abstract}
Condit Dam, at river kilometer 5.3 on the White Salmon River, Washington, was breached in 2011 and removed completely in 2012, allowing anadromous salmonids access to habitat that had been blocked for nearly 100 years. A multi-agency workgroup concluded that the preferred salmonid restoration alternative was natural recolonization with monitoring to assess efficacy, followed by a management evaluation 5 years after dam removal. Limited monitoring of salmon and steelhead spawning has occurred since 2011, but no monitoring of juveniles occurred until 2016. During 2016, we operated a rotary screw trap at river kilometer 2.3 (3 kilometers downstream of the former dam site) from late March through May and used backpack electrofishing during summer to assess juvenile salmonid distribution and abundance. The screw trap captured primarily steelhead (Oncorhynchus mykiss; smolts, parr, and fry) and coho salmon (O. kisutch; smolts and fry). We estimated the number of steelhead smolts at 3,851 (standard error $=1,454$ ) and coho smolts at 1,093 (standard error $=412$ ). In this document, we refer to $O$. mykiss caught at the screw trap as steelhead because they were actively migrating, but because we did not know migratory status of $O$. mykiss caught in electrofishing surveys, we simply refer to them as $O$. mykiss or steelhead/rainbow trout. Steelhead and coho smolts tagged with passive integrated transponder tags were subsequently detected downstream at Bonneville Dam on the Columbia River. Few Chinook salmon (O. tshawytscha) fry were captured, possibly as a result of trap location or effects of a December 2015 flood. Sampling in Mill, Buck, and Rattlesnake Creeks (all upstream of the former dam site) showed that juvenile coho were present in Mill and Buck Creeks, suggesting spawning had occurred there. We compared O. mykiss abundance data in sites on Buck and Rattlesnake Creeks to pre-dam removal data. During 2016, age-0 O. mykiss were more abundant in Buck Creek than in 2009 or 2010, though age-1 and older $O$. mykiss abundance was similar. In Rattlesnake Creek, age-0 O. mykiss abundance during 2016 slightly exceeded the mean abundance from 2001 through 2005, although age-1 and older O. mykiss abundance was lower than from 2001 through 2005. These sampling efforts also provided the opportunity to collect genetic samples to investigate parental and stock origin, although funding to analyze the samples was not part of this grant. Juvenile salmonid sampling efforts during 2016 have shown that natural spawning produced steelhead and coho smolts and that coho were colonizing some tributaries. The 2016 efforts also provided the first post-dam juvenile abundance estimates. We hope to continue monitoring to better understand abundance trends, distribution, and life history patterns of recolonizing salmonids in the White Salmon River to assess efficacy of natural recolonization and to inform management decisions.
\end{abstract}




\section{Introduction}

Condit Dam, on Washington's White Salmon River, blocked fish passage for nearly 100 years. The dam, at river kilometer (rkm) 5.3, was breached in 2011 and completely removed by September 14, 2012. Ongoing mitigation and restoration efforts include sediment stabilization and re-vegetation of the newly exposed reservoir sediment (Greenworks and others, 2011; Inter-Fluve, 2013). Currently, the river is in a state of flux, with riparian re-vegetation occurring in the former reservoir reach, and a large volume of sediment and gravel redistributing between the former dam site and the confluence with the Columbia River. Gravel bars and shoreline from the reservoir reach to the Columbia River change with each high water event (Wilcox and others, 2014; Hatten and others, 2016). The White Salmon River historically supported steelhead trout (Oncorhynchus mykiss), spring and fall Chinook salmon (O. tshawytscha), coho salmon (O. kisutch), and chum salmon (O. keta) runs (Lane and Lane Associates, 1981; Cowan, 1999; National Marine Fisheries Service, 2013a, 2013b), and provided local Native Americans with important fishing areas (National Marine Fisheries Service, 2013b).

The White Salmon watershed is part of the Lower Columbia River (LCR) Evolutionary Significant Unit (ESU) salmon recovery domain and the Middle Columbia River (MCR) Distinct Population Segment (DPS) steelhead recovery domain, as well as the State's Water Resource Inventory Area (WRIA) 29b (Cowan, 1999; National Marine Fisheries Service, 2009, 2013b). Removal of Condit Dam opened passage for anadromous salmonids, including LCR Chinook salmon (both fall and spring runs), LCR coho salmon, and MCR steelhead, which are all listed as threatened under the Endangered Species Act (ESA; National Marine Fisheries Service, 2009, 2013a, 2013b). White Salmon River fall and spring Chinook salmon are contributing populations in the Gorge Strata of the LCR ESU, and White Salmon River coho salmon are a part of the primary population of the upper part of the Gorge Strata (Lower Columbia Fish Recovery Board, 2010a). However, the ESA Recovery Plan for the White Salmon River Watershed (National Marine Fisheries Service, 2013b) suggests White Salmon River coho may be functionally extinct and spring Chinook salmon likely extirpated. White Salmon River steelhead are part of the East Cascades Major Population Group (MPG) of the MCR steelhead DPS and may include one of the most inland runs of winter steelhead (National Marine Fisheries Service, 2013b). In this document, we refer to $O$. mykiss caught at the screw trap as steelhead because they were actively migrating, but because we did not know migratory status of $O$. mykiss caught in electrofishing surveys, we simply refer to them as $O$. mykiss or steelhead/rainbow trout. The Middle Columbia River Steelhead ESA Recovery Plan (National Marine Fisheries Service, 2009) considers White Salmon steelhead "functionally extirpated." However, based on migratory life-histories identified by pre-dam removal studies, the plan recognizes that some potential for anadromy remains from the $O$. mykiss populations that were isolated upstream of Condit Dam.

Tagging of $O$. mykiss with radio and passive integrated transponder (PIT) tags upstream of Condit Dam prior to its removal demonstrated migratory life-histories and potential smoltification. Tagged O. mykiss from Rattlesnake Creek, the White Salmon River, and Northwestern Lake (the impoundment behind Condit Dam) demonstrated fluvial and adfluvial life histories (U.S. Geological Survey, unpub. data, 2003; Allen, Connolly, Jezorek, and others, 2006). During pre-dam removal studies, one $O$. mykiss PIT tagged in Buck Creek and one PIT tagged in Rattlesnake Creek were detected at Bonneville Dam, and a PIT tag from an additional fish from Rattlesnake Creek was detected on East Sand Island in the Columbia Estuary. These detections in the Columbia River downstream of Condit Dam suggest that some $O$. mykiss from the White Salmon River watershed may still have been expressing an anadromous life-history. 
The removal of Condit Dam has reopened a large amount of habitat for anadromous fish. Condit Dam blocked 27 kilometers $(\mathrm{km})$ of potential coho salmon habitat, $15 \mathrm{~km}$ of potential spring Chinook salmon habitat, $7 \mathrm{~km}$ of potential fall Chinook salmon habitat, and $50 \mathrm{~km}$ of potential steelhead habitat (Northwest Power and Conservation Council, 2004; National Marine Fisheries Service, 2013a, 2013b). In addition to newly accessible habitat upstream of the dam site, areas downstream of the Condit Dam site have improved for salmonid spawning and rearing as gravel and cobbles have distributed through the downstream reaches (Hardiman and Allen, 2015; Hatten and others, 2016). The newly accessible and improved areas of the White Salmon River comprise a significant habitat gain in the Gorge Strata of the LCR ESU and the East Cascades MPG of the MCR DPS.

Numerous Federal and State plans call for monitoring of listed stocks in ESUs and their subunits to gage Viable Salmonid Population (VSP) status and trends (McElhany and others, 2000; National Marine Fisheries Service, 2009, 2013a, 2013b; Lower Columbia Fish Recovery Board, 2010a, 2010b). These data include direct measures, or indices of, abundance, population growth rate, population spatial structure, and diversity. Managers need data on VSP attributes to inform population trends and status of stocks listed as threatened under the ESA.

Prior to removal of Condit Dam, the White Salmon Technical Work Group (WSTWG) was formed to develop a strategy for restoration of anadromous fish runs. The group included representatives of USGS, U.S. Fish and Wildlife Service (USFWS), U.S. Forest Service, Yakama Nation (YN), Washington Department of Fish and Wildlife (WDFW), National Marine Fisheries Service (NMFS), and PacifiCorp. Between February 2006 and November 2014, the WSTWG analyzed options for salmonid recovery and re-introduction to the White Salmon River for each salmonid species that had been extirpated upstream of Condit Dam. The WSTWG recommended allowing natural recolonization for each species with 5 years of post-dam removal monitoring (National Marine Fisheries Service, 2013b). Following the initial recolonization period, monitoring data would be examined and decisions about recolonization success, management, and supplementation options would be reconsidered for individual species as needed (Allen and others, 2016). The WSTWG's recommendations were accepted by NMFS and incorporated into the ESA Recovery Plan for the White Salmon River Watershed (National Marine Fisheries Service, 2013b). However, available funding for monitoring has been minimal.

The NMFS's ESA Recovery Plan for the White Salmon River Watershed (National Marine Fisheries Service, 2013b) sets abundance goals for fall Chinook salmon, spring Chinook salmon, coho salmon, chum salmon, and steelhead. The Recovery Plan calls for a monitoring program as a key action to the successful implementation of the plan. Key questions, outlined in the monitoring section of the ESA Recovery Plan for the White Salmon River, are-what is the source and abundance of colonizing salmon and steelhead, what is the productivity of those fish, what are limiting factors by life stage, and are they producing viable offspring to support population persistence? These questions can be assessed by investigating the VSP parameters of abundance, distribution, productivity, and life-stage survival.

The ESA Recovery Plan for the White Salmon River specifically calls for efforts to "monitor of current population status and habitat conditions and to improve the likelihood that efforts to reintroduce salmon and steelhead in the White Salmon River are efficient and successful." The monitoring efforts include assessing change in resident populations after steelhead recolonization, population monitoring in the White Salmon River and major anadromous tributaries, PIT tagging of juvenile salmonids each year to track movement and growth rates, and genetic analysis of smolts and adult salmonids. Population viability criteria can include juvenile out-migrant productivity and trends, population diversity, and spatial structure. Data outlined in the ESA Recovery Plan for the White Salmon River Watershed will inform managers about specifics to White Salmon River and Gorge strata populations, but will also contribute to the growing body of science focused on dam removal. 
Dam removals have increased nationwide (O'Connor and others, 2015; Bellmore and others, 2016). Dam removal often involves uncertainty and management concerns regarding the removal's physical and biological consequences (Tullos and others, 2016). Many dam removals are not scientifically monitored for biological effects or are monitored for only a short duration (O'Connor and others, 2015; Bellmore and others, 2016; Brewitt, 2016). More and longer duration dam removal response studies are required to begin to develop predictive models to inform managers and the public about effects of dam removal (Gregory and others, 2002; Hart and others, 2002; Pess, 2009; Brewitt, 2016).

The removal of Condit Dam provides an opportunity to evaluate the efficacy of dam removal as a restoration strategy and to contribute to the science of dam removals. Condit Dam is a relatively unique case to date because it was a high dam (38 meters [m]), and a large amount of sediment was released (1.8 million cubic meters $\left[\mathrm{m}^{3}\right]$; Wilcox and others, 2014; O'Connor and others, 2015). Study of anadromous salmonid recolonization in the White Salmon River is also valuable because no hatchery fish are currently planted in the watershed. Additionally, there are some data on fish in the White Salmon River pre-dam removal, and many dam removals occur with little to no pre-removal data (Bellmore and others, 2016).

Several studies occurred in the White Salmon River both upstream and downstream of Condit Dam prior to removal. In both Buck and Rattlesnake Creeks, USGS assessed abundance of $O$. mykiss and collected extensive habitat data. Studies of fish abundance and distribution were done in Rattlesnake Creek from 2001 to 2005 (Allen and others, 2003a, 2003b; Allen, Connolly, Jezorek, and others, 2006; Allen, Connolly, Munz, and others, 2006) and in Buck Creek during 2009 and 2010 (Allen and others, 2012).

To determine species composition and relative abundance downstream of Condit Dam, USGS and USFWS used a rotary screw trap to assess juvenile fish from 2006 through 2009 (Allen and Connolly, 2011). Genetic samples from Chinook fry captured in the screw trap were analyzed by USFWS to determine the relatedness of those fish to nearby hatchery tule fall Chinook stocks and upriver bright fall Chinook populations that stray and spawn in the lower White Salmon River (Smith and Engle, 2011). These projects found that, although the non-native upriver bright fall Chinook spawned in greater numbers (based on data from WDFW spawning surveys), the native "tule" fall Chinook outmigrated in greater numbers. These existing pre-dam removal data offer a baseline for understanding changes in fish distribution, abundance, and genetics.

Since removal of Condit Dam, some limited monitoring work on the White Salmon River has been planned and initiated by the WSTWG, and the members continue to coordinate efforts (Allen and others, 2016) despite minimal funding. The USFWS did Chinook salmon spawning surveys in 2012. WDFW has done Chinook salmon spawning (spring and fall run) surveys since 2013, following VSP guidelines (McElhany and others, 2000; Crawford and Rumsey, 2011) to estimate adult abundance and distribution and to investigate adult origin through tag recovery and genetic sampling (Hardiman and Allen, 2015; Allen and others, 2016; Hatten and others, 2016; Washington Department of Fish and Wildlife, unpub. data, 2017).

Yakama Nation has done steelhead spawning surveys in tributaries since 2012 (Allen and others, 2016; Joe Zendt, Yakama Nation Fisheries, written commun., 2016). Steelhead spawning survey limitations resulting from inherent sampling difficulties (prolonged spawning period, high flows, turbidity, iteroparity) are exacerbated by the confined and high gradient character of the mainstem White Salmon River. Steelhead spawning surveys are providing spatial distribution data and an index of abundance in the tributaries, but not a subbasin population estimate. Because of funding limitations and challenges of surveying adult steelhead, an approach that includes smolt and juvenile abundance and life history data is needed. The Lower Columbia Fish Recovery Board's Research Monitoring and Evaluation Program for Lower Columbia Salmon and Steelhead (Lower Columbia Fish Recovery 
Board, 2010a) states, "Juvenile surveys are particularly useful for population status assessments where spawner surveys are difficult," and that "juvenile census sampling can provide extensive information on abundance and productivity." A combination of adult and juvenile monitoring will provide the most robust information to assess efficacy of natural recolonization and to inform management actions in the White Salmon River watershed.

No assessment of adult coho salmon use of the White Salmon River has been done since dam removal. Like steelhead, adult coho sampling in the White Salmon River has significant challenges and limitations. Similar to steelhead, an approach that includes smolt and juvenile abundance and life history data will provide the most robust information to assess efficacy of natural recolonization.

The WSTWG continues to meet to coordinate ongoing efforts in the White Salmon River (Allen and others, 2016) and to work on the White Salmon River Aquatic Monitoring Plan Working Draft (unpub. data, 2016). Research and monitoring of anadromous salmonid distribution and populations in the White Salmon River has been recommended by National Marine Fisheries Service ESA Recovery Plan for the White Salmon River Watershed (National Marine Fisheries Service, 2013b), National Marine Fisheries Service Lower Columbia River Salmon and Steelhead ESA Recovery Plan (National Marine Fisheries Service, 2013a), National Marine Fisheries Service Middle Columbia River Steelhead ESA Recovery Plan (National Marine Fisheries Service, 2009), the Klickitat Lead Entity Region Salmon Recovery Plan (2013), and the WSTWG (Allen and others, 2016). To date, WDFW is surveying adult Chinook salmon spawning (Jeremy Wilson, Washington Department of Fish and Wildlife, written commun., 2016), and YN is surveying steelhead spawning in tributaries, with hope for an increased effort during 2017 (Joe Zendt, Yakama Nation Fisheries, written commun., 2016). The USFWS is considering installing an instream PIT tag detection system near the mouth of the White Salmon River to help address concerns regarding potential effects from hatchery origin Chinook Salmon spawning with wild or recovering populations (Dammerman and others, 2016), and investigating distribution of Pacific lamprey (Entosphenus tridentatus; Jolley and others, 2013).

During 2016, USGS began the first monitoring of juvenile salmonids in the White Salmon River since dam removal. Funding for this work was provided through Mid-Columbia Fisheries Enhancement Group (MCFEG), which procured a grant from the Washington State Salmon Recovery Funding Board. The goals of our work were to assess smolt production from anadromous spawning upstream of rkm 2.3, juvenile salmonid distribution throughout the watershed, and juvenile salmonid abundance in select reaches of two primary tributaries of the White Salmon River. We assessed smolt production with a rotary screw trap at rkm 2.3 following standard protocols outlined in Volkhardt and others (2007). This site is a new location for a rotary screw trap in the White Salmon (the site used from 2006 through 2009 is no longer viable due to sediment deposition, a very dynamic channel, and lack of access), and this early monitoring will serve to assess sampling efficacy at rkm 2.3 and provide guidance for longer term efforts. We assessed juvenile salmonid distribution and abundance by backpack electrofishing with mark-recapture protocols of Temple and Pearsons (2007). Additionally, because we used PIT tags for mark-recapture estimates, future recaptures or detections of these fish will contribute to knowledge of life-history diversity of naturally produced salmonids in the White Salmon River. These data will help evaluate the efficacy of dam removal as a restoration strategy, the efficacy of a natural recolonization strategy for anadromous salmonids, and inform managers of the status of salmonid stocks listed as threatened under the Endangered Species Act. 


\section{Description of Study Site}

The White Salmon River watershed encompasses about 1,000 square kilometers $\left(\mathrm{km}^{2}\right)$ of Klickitat, Yakima, and Skamania Counties in south-central Washington (Haring, 2003). The White Salmon River is a tributary of the Columbia River at rkm 270 (fig. 1). The topography of the surrounding area is highly varied, including mountainous terrain, deeply incised canyons, rolling hills, and low-gradient valley floors (Northwest Power and Conservation Council, 2004; National Marine Fisheries Service, 2013b). The White Salmon River is in the transitional eco-tone between the more moderate coastal maritime climate zone and the more continental inland climate zone. The climate is temperate, and around 80 percent of the annual precipitation occurs between October and March. Precipitation in the winter is primarily rain in the lower watershed and rain or snow in the higher altitudes and ranges from $100 \mathrm{~cm}$ in the east to $240 \mathrm{~cm}$ in the north and west (Northwest Power and Conservation Council, 2004).

The mainstem White Salmon River has good water quantity and quality (Haring, 2003; Northwest Power and Conservation Council, 2004; Allen and Connolly, 2005). Discharge in the mainstem ranges from a daily mean of about $19 \mathrm{~m}^{3} / \mathrm{s}$ during fall to about $44 \mathrm{~m}^{3} / \mathrm{s}$ in spring (U.S. Geological Survey streamgage 14123500 [White Salmon River near Underwood, WA]; Haring, 2003). Water temperatures in the mainstem remain cold throughout the year, with maximum and minimum temperatures and dissolved oxygen concentrations favorable for salmonids. Discharge is maintained by cold springs and seeps coming from high-altitude snowmelt throughout the summer (Haring, 2003; Northwest Power and Conservation Council, 2004; Allen and Connolly, 2005). Much of the mainstem White Salmon River is in a narrow naturally incised bedrock and boulder canyon (Northwest Power and Conservation Council, 2004; Plummer and Zuckerman, 2012).

There are many waterfalls on the mainstem White Salmon River. The largest is Big Brother Falls (about 7.3 meters [m] high) at rkm 26, which is likely the upstream extent of anadromous distribution (some anecdotal reports mention steelhead upstream of these falls, but are unconfirmed). BZ Falls (about $4.5 \mathrm{~m}$ high) is at rkm 20 and is likely a barrier to salmon, though steelhead can most likely ascend it (Reiser and others, 2006). Husum Falls (about $3 \mathrm{~m} \mathrm{high)} \mathrm{is} \mathrm{at} \mathrm{rkm} \mathrm{12.2,} \mathrm{and} \mathrm{is} \mathrm{a} \mathrm{barrier} \mathrm{to}$ some salmon, though spring Chinook salmon, and their redds have been found upstream of it (Allen and others, 2016; Jeremy Wilson, Washington Department of Fish and Wildlife, written commun., 2016).

The characteristics of the lower $8.0 \mathrm{~km}$ of the mainstem White Salmon River have rapidly changed since the 2011 breaching of Condit Dam at rkm 5.3 and subsequent sediment release. At the time that Condit Dam was breached, an estimated 1.8 million $\mathrm{m}^{3}$ of reservoir sediments were impounded in the reservoir (Wilcox and others, 2014). The dam was abruptly breached with an explosive blast that opened a $3.6 \times 5.5 \mathrm{~m}$ hole at the base of the dam that rapidly emptied the reservoir and much of the sediment consisting mostly of sand, silt, and clay (Wilcox and others, 2014). This exposed the old river channel in the reservoir reach and the outflow of silt, sand, and gravel filled pools throughout the lower river, created gravel bars, and a delta at the confluence with the Columbia River. This influx of sediment to the lower river has increased potential salmonid spawning habitat (Hardiman and Allen, 2015; Hatten and others, 2016). Natural watershed processes delivering large woody debris, cobbles, and gravel to the lower reaches have been restored (Wilcox and others, 2014; Hardiman and Allen, 2015; Allen and others, 2016; Hatten and others, 2016). The lower river will likely be in a state of flux for the next few years as the river channel continues to stabilize and the riparian corridor reestablishes. 

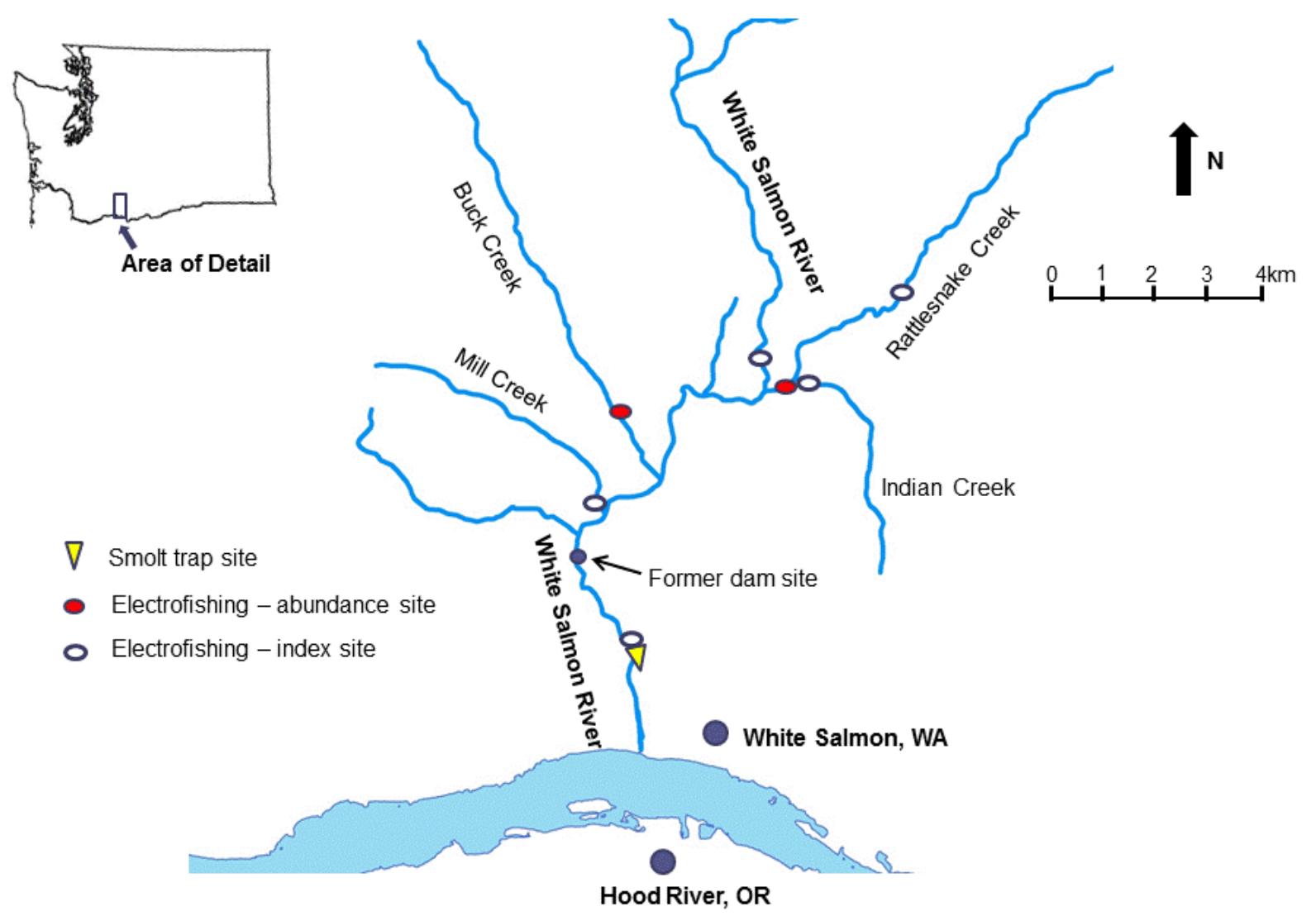

Figure 1. Map showing the White Salmon River watershed accessible to anadromous salmonids and locations of rotary screw trapping and electrofishing surveys, Washington, 2016. The former location of Condit Dam, which was breached in 2011, also is shown.

Four tributaries to the White Salmon River in our study area had anadromous fish access. Mill, Buck, Spring, and Rattlesnake Creeks all enter the White Salmon River between the former dam site and Husum Falls. We sampled fish in Mill, Buck, and Rattlesnake Creeks, but did not have permission to access Spring Creek.

Mill Creek flows to the White Salmon River from the west at rkm 6.4 (fig. 1). The drainage basin is $11 \mathrm{~km}^{2}$, with a mix of private and Washington State owned lands. Altitude at the confluence with the White Salmon River is about $90 \mathrm{~m}$, with the upper headwaters at about $800 \mathrm{~m}$. The basin is steep and heavily forested. Plummer and Zuckerman (2012) reported many springs contributing flow to Mill Creek, which presumably maintain low water temperatures and a streambed with many areas of gravel and cobble suitable for spawning. The estimates of potential habitat for anadromous fish in Mill Creek range from 3.2 to $7 \mathrm{~km}$ (Northwest Power and Conservation Council, 2004; Plummer and Zuckerman, 2012). 
Buck Creek flows into the White Salmon River from the northwest at rkm 7.5 (fig. 1). The Buck Creek drainage basin is steep, mountainous terrain. The area of the drainage basin is $36 \mathrm{~km}^{2}$, approximately 90 percent of which has been managed by Washington State Department of Natural Resources (WDNR) since 1921. Altitude in the drainage basin ranges from $92 \mathrm{~m}$ at its mouth to $1,219 \mathrm{~m}$ at its headwaters. The drainage basin is characterized by primarily forested (second growth and early successional mixed conifer and deciduous), steep canyons with an incised basalt bedrock channel. Since 1923, the City of White Salmon has been diverting water for its municipal supply from Buck Creek, with a 10-year hiatus during 2000-10 due to surface water contamination. Buck Creek was brought back online as the consumptive supply source on July 23, 2010, after completion of construction of the Buck Creek sand filtration plant at $327 \mathrm{~m}$ altitude downstream of the city's concrete headworks dam.

Allen and others (2012) defined four reaches in the part of Buck Creek accessible to anadromous fish. Reach 1 begins at the confluence with the White Salmon River and extends upstream $2.0 \mathrm{~km}$ to a narrowing of valley confinement. Reach 2 was confined by valley walls and extended from rkm 2.0 to 3.1 , where there is a $1.1-\mathrm{m}$ high irrigation diversion $(0.76-\mathrm{m}$ high concrete dam with $0.35-\mathrm{m}$ high seasonal, wooden flash boards), which has a water right for $0.004 \mathrm{~m}^{3} / \mathrm{s}$ (Aspect Consulting, 2011). Reach 3 extended from rkm 3.1 to 5.0, where there is a $4.3-\mathrm{m}$ waterfall. Reach 4 extended from rkm 5.0 to 6.4, where there is a 6-m waterfall (the likely end of anadromy and immediately downstream of the City of White Salmon municipal water facility). Habitat survey by Allen and others (2012) found that the majority of habitat in Buck Creek was large cobble riffles. Boulders and cobbles were the dominant substrate with limited spawning gravel. They found instream large woody debris (LWD) to be less frequent and smaller than reported for unmanaged basins of similar size and character.

Minimum discharge in Buck Creek was reported by Allen and others (2012) as $0.02 \mathrm{~m}^{3} / \mathrm{s}$ at the mouth, and $0.009 \mathrm{~m}^{3} / \mathrm{s}$ downstream of the water diversion at $\mathrm{rkm} 3.1$. Water temperatures in Buck Creek have been favorable to salmonids. Temperatures at the lower end of Buck Creek only occasionally exceeded $16^{\circ} \mathrm{C}$ and never exceeded $18^{\circ} \mathrm{C}$ during 2009 and 2010 (Allen and others, 2012).

Rattlesnake Creek flows to the White Salmon River from the east at rkm 13.8 (fig. 1). The Rattlesnake Creek watershed covers $143 \mathrm{~km}^{2}$, nearly all privately owned forest and agricultural land. Altitude is about $114 \mathrm{~m}$ at the mouth, which is at the watershed's western boundary, to $927 \mathrm{~m}$ at ridge tops near its eastern edge. There are two notable sets of waterfalls in Rattlesnake Creek. The lower set of falls, at rkm 2.4, has three individual drops, with the middle one being the largest (about $3.6 \mathrm{~m}$ total height, but with a step and $1.5 \mathrm{~m}$ deep pocket at $2.1 \mathrm{~m}$ ). The lower falls are likely a barrier to resident fish, but may be passable to salmon and steelhead. An adult steelhead was sighted upstream of these falls during 2016 (Joe Zendt, Yakama Nation Fisheries, written. commun., 2016). The upper falls, at rkm 17, has two separate drops of about 22-25 m each and is a fish barrier.

Allen, Connolly, Jezorek, and others (2006) defined four reaches in Rattlesnake Creek based on geomorphology and potential fish barriers. The lowermost reach was from the confluence with the White Salmon to the lower set of waterfalls at about rkm 2.4. The next reach was a canyon section that extended from the lower falls for about $3.1 \mathrm{~km}$ to a lessening of valley confinement. The next upstream reach was a less constrained alluvial reach extending $5.3 \mathrm{~km}$ to the beginning of another canyon section. The uppermost reach extended about $6.6 \mathrm{~km}$ to the base of the upper falls. Allen, Connolly, Jezorek, and others (2006) reported that habitat conditions in all reaches of Rattlesnake Creek were poor. Pool frequency and quality were low. Counts of LWD were low, and in many areas riparian condition was degraded (Allen, Connolly, Jezorek, and others, 2006; Plummer and Zuckerman, 2012). 
Discharge in Rattlesnake Creek is extremely low during summer (Northwest Power and Conservation Council, 2004; Allen and Connolly, 2005; Allen, Connolly, Jezorek, and others, 2006; Allen, Connolly, Munz, and others, 2006; Plummer and Zuckerman, 2012). Discharge near the mouth of Rattlesnake Creek can be less than $0.0018 \mathrm{~m}^{3} / \mathrm{s}$, and surface flow in riffles is barely discernible in some upstream reaches. Water temperature in Rattlesnake Creek is high and can approach lethal limits for salmonids. Allen, Connolly, Jezorek, and others (2006) reported a max temperature of $23.6{ }^{\circ} \mathrm{C}$ at $\mathrm{rkm}$ 0.9 , and temperatures exceeding $20{ }^{\circ} \mathrm{C}$ throughout the drainage were common.

\section{Study Methods}

\section{Smolt Trapping}

We installed and operated a 1.5-m rotary screw trap (E.G. Solutions, Corvallis, Oregon) at rkm 2.3 of the White Salmon River (fig. 1; table 1). This was the first location upstream of the confluence with the Columbia River, where channel characteristics and access enabled us to operate a trap. We fished the trap continuously from March 24 to May 28, 2016. Smolt migrant estimates were generated following methods outlined in Volkhardt and others (2007), by marking fish, releasing them upstream, and generating trap capture efficiency from recaptured fish.

Each day, debris was removed from the live box, and captured fish were netted into buckets and transported to shore. Captured fish were held in buckets or coolers with ambient aerated stream water. Fish were anesthetized with $50 \mathrm{mg} / \mathrm{L}$ tricaine methanesulfonate (MS-222), identified to species, measured for fork length (FL) to the nearest millimeter, weighed to the nearest $0.1 \mathrm{~g}$, and classified by life stage (fry, parr, smolt). Salmonids were checked for marks to determine if they were recaptures. Fish 70-mm or greater FL were scanned for PIT tags and PIT tagged (12-mm, $134.2 \mathrm{kHz}$ tags; Biomark, Boise, Idaho) if not previously tagged. Tags were injected into the peritoneal cavity following methods outlined by Columbia Basin Fish and Wildlife Authority (2014). For salmonids less than 70-mm FL, an upper or lower caudal fin clip was collected for a mark. These tissue samples, and fin clips collected from most other fish, were archived for genetic sampling (including lamprey).

Capture efficiency, defined as the percentage of fish passing the trap that are captured (Thedinga and others, 1994), is an important variable to measure to estimate the total number of migrating fish. We calculated migrant estimates following standard methods outlined in Volkhardt and others (2007). Each day, newly marked fish (PIT-tagged or fin clipped) were transported by vehicle to an access point at the PacifiCorp Powerhouse at $\mathrm{rkm} 3.0$ where they were released. Recaptured fish were released each day downstream of the trap. We estimated the number of smolt migrants and associated variance as:

$$
\begin{gathered}
\hat{U}=\frac{u(M+1)}{(m+1)} \\
V(\hat{U})=\frac{(M+1)(u+m+1)(M-m) u}{(m+1)^{2}(m+2)}
\end{gathered}
$$

where,

$\begin{aligned} \hat{U} & =\text { estimate of unmarked fish migrating during sample period, } \\ u & =\text { number of unmarked fish captured during sample period, } \\ M & =\text { number of fish marked and released during sample period, } \\ m & =\text { number of marked fish captured during sample period, and } \\ V & =\text { variance. }\end{aligned}$


Table 1. Latitude and longitude (decimal degrees) of fish sampling and water temperature monitoring locations, White Salmon River watershed, Washington, 2016.

[Sample type: Ef. Dist., electrofishing distribution survey; Temp., temperature logger site; Ef. Ab., electrofishing abundance survey]

\begin{tabular}{|c|c|c|c|c|c|c|}
\hline \multirow{3}{*}{ Site } & \multirow{3}{*}{ Date } & \multirow{3}{*}{$\begin{array}{c}\text { Sample } \\
\text { type }\end{array}$} & \multicolumn{4}{|c|}{ Sample site coordinates } \\
\hline & & & \multicolumn{2}{|c|}{ Start point } & \multicolumn{2}{|c|}{ End point } \\
\hline & & & Latitude & Longitude & Latitude & Longitude \\
\hline White Salmon River ${ }^{1}$ & & Screw trap ${ }^{2}$ & 45.74764 & -121.52110 & - & - \\
\hline White Salmon River & 08-02-2016 & Ef .Dist. & 45.74774 & -121.52104 & 45.74941 & -121.52378 \\
\hline White Salmon River & 08-03-2016 & Ef. Dist. & 45.79955 & -121.48559 & 45.80063 & -121.48618 \\
\hline White Salmon River & & Temp. $^{3}$ & 45.74769 & -121.52105 & & \\
\hline White Salmon River & & Temp. & 45.79973 & -121.48571 & & \\
\hline Mill Creek & $07-25-2016$ & Ef. Dist. & 45.77476 & -121.52991 & 45.77617 & -121.53199 \\
\hline Mill Creek & $08-08-2016$ & Ef. Dist. & 45.77842 & -121.53225 & 45.77934 & -121.53187 \\
\hline Mill Creek & & Temp. & 45.77834 & -121.53207 & & \\
\hline Buck Creek & $07-28,29-2016$ & Ef.Ab. & 45.79603 & -121.52914 & 45.79776 & -121.52980 \\
\hline Buck Creek & & Temp. & & & & \\
\hline Rattlesnake Creek & 09-01-2016 & Ef. Dist. & 45.79737 & -121.48047 & 45.79846 & -121.47850 \\
\hline Rattlesnake Creek & $10-19-2016$ & Ef. Dist. & 45.81061 & -121.46128 & 45.81218 & -121.45680 \\
\hline Rattlesnake Creek & & Temp. & 45.79706 & -121.48521 & & \\
\hline Indian Creek & $07-27-2016$ & Ef. Dist. & 45.79941 & -121.47773 & 45.79928 & -121.47690 \\
\hline Rattlesnake Creek & $07-26,27-2016$ & Ef. Ab. & 45.79759 & -121.48174 & 45.79780 & -121.47903 \\
\hline
\end{tabular}

${ }^{1}$ The White Salmon River screw trap operated from March 24 to May 28, 2016.

${ }^{2}$ Screw trap was a fixed sampling location, thus only one point.

${ }^{3}$ Temperature loggers were at fixed locations, deployed from June 3 to November 14, 2016.

All screw trap data were electronically entered on a field computer provided by WDFW, and configured to accept data into their Juvenile Migrant Exchange (JMX) database. All screw trap data from 2016 was entered into the JMX database. All mark and recapture data from PIT-tagged fish were provided to the PTAGIS database administered by Pacific States Marine Fisheries Commission. Estimates of smolt migrants will be provided to the Coordinated Assessments Database. 


\section{Electrofishing}

\section{Distribution Electrofishing}

We used backpack electrofishing to investigate distribution and assemblage of salmonids in the watershed (primarily salmon because $O$. mykiss were known to be throughout the watershed). In the mainstem White Salmon River, we sampled at rkm 2.3 and 12.3 (fig. 1, table 1). The site at rkm 2.3 provided a comparison to sampling done at that site by Allen and Connolly (2011). The rkm 12.3 site was just upstream of Husum Falls to investigate potential presence of spring Chinook or coho salmon. Methods for sampling the White Salmon at rkm 2.3 and 12.3 were similar to methods implemented by Connolly and Brenkman (2008) in the Elwha River system and used in the White Salmon River by Allen and Connolly (2011). At each location, a 4.5-m swath of the wadeable-margin was electrofished, with an attempt to sample at least one pool and one non-pool habitat. These margin sampling efforts will serve as index areas to document assemblage and relative abundance of fish.

We also backpack-electrofished for fish distribution and species assemblage in Mill Creek, a section of Rattlesnake Creek, and in Indian Creek, which is a small tributary to Rattlesnake Creek at rkm 0.8 (fig. 1; table 1). In Mill Creek, we sampled from the mouth upstream about $250 \mathrm{~m}$, and at a 60$\mathrm{m}$ section where Lakeview Road crosses the creek at rkm 0.5 . The effort at the road crossing was to assist Underwood Conservation District in removing and relocating fish from the construction area for a culvert replacement project (culvert replacement was funded partially by the Washington State Salmon Recovery Funding Board). This effort provided us the opportunity to sample an additional location in Mill Creek. In Rattlesnake Creek, we did an assemblage and distribution sample in the reach upstream of the lower set of falls. This sample was prompted by the sighting of an adult steelhead in this reach during spring 2016 (Joe Zendt, Yakama Nation Fisheries, written commun., 2016). The sample in Indian Creek was from its confluence with Rattlesnake Creek upstream about $50 \mathrm{~m}$ to a road crossing. Fish collected in distribution and assemblage electrofishing samples were held in buckets with ambient, aerated stream water. Captured fish were anesthetized with the lightest possible dose of MS222 then measured for FL to the nearest millimeter, weighed to the nearest $0.1 \mathrm{~g}$ and scanned for PIT tags. Salmonids 70-mm FL or greater were PIT tagged (12-mm, $134.2 \mathrm{kHz}$ tags). Small fin clips were collected from most fish and archived for genetic sampling. After fish recovered, they were released as close as possible to the point of capture. These distribution and assemblage samples will serve as index areas to document juvenile fish use, species diversity and relative abundance, assess life-history traits via PIT tagging, and provide tissue sampling for genetic analysis.

\section{Abundance Electrofishing}

We used backpack electrofishing to assess juvenile salmonid abundance in the most downstream reach of Rattlesnake Creek and reach 2 of Buck Creek, both of which had pre-dam removal data (Allen, Connolly, Jezorek, and others, 2006; Allen and others, 2012). We estimated abundance of fish using the mark-recapture methods outlined in Temple and Pearsons (2007). Each stream section was about 200-m long, and we block-netted the stream at the upstream and downstream ends. We used two block nets at each end of the sample section, one (of coarser mesh) was placed upstream of the other to collect some of the material brought down by the current and ensure that the lower net was not knocked down by debris loading. The net lead lines were secured snugly to the streambed with boulders and large cobble and the upper net line was tied off so that it was at least $0.5 \mathrm{~m}$ above the water surface. 
Once the nets were secured to prevent immigration or emigration, we did a marking effort by electrofishing the section in a pass upstream and back. Two or three crew members dipnetted fish, which were immediately placed in buckets or coolers with ambient, aerated stream water. Captured fish were anesthetized with the lightest possible dose of MS-222, measured for FL to the nearest millimeter, weighed to the nearest $0.1 \mathrm{~g}$, and marked. Fish 70-mm FL or greater were PIT tagged (12-mm, 134.2 $\mathrm{kHz}$ ), smaller fish were given a caudal fin clip. Fish were released as close as possible to their point of capture. We then left the block nets up overnight and returned the following day when we repeated the electrofishing for a recapture pass in the block-netted area. During fish workup for the recapture pass, all fish were checked for PIT tag or fin clip marks. We used length-frequency histograms to assign ages to age- 0 and age- 1 or older fish (figs. A1-A9).

For mark-recapture analysis we followed methods outlined in Temple and Pearsons (2007), we estimated the population of fish and associated variance, by species and age class (age- 0 and age- 1 and older), as:

$$
\begin{aligned}
& \hat{N}=\left[\frac{(M+1)(C+1)}{(R+1)}\right]-1 \\
& V(\hat{N})=\frac{\left(\hat{N}^{2}\right)(C-R)}{(C=1)(R+2)}
\end{aligned}
$$

where

$$
\begin{aligned}
\hat{N} & =\text { population estimate } \\
M & =\text { number of fish marked during the mark sample effort, } \\
C & =\text { total number of fish captured in the recapture sample effort, } \\
R & =\text { number of marked fish captured in the recapture sample effort, and } \\
V & =\text { variance. }
\end{aligned}
$$

To quantify habitat area, we took width and depth measurements at 10 transects, equally spaced through the mark-recapture section. With these data we calculated the area of the section and were able to estimate fish per meter (fish/m) and fish per square meter (fish $\left./ \mathrm{m}^{2}\right)$. 


\section{Water Temperature}

We deployed five Onset Optic Stowaway ${ }^{\circledR}$ (Onset Computer Corp., Bourne, Massachusetts) thermologgers in our study area (table 2). Two were in the mainstem White Salmon River, one was at the screw trap site at rkm 2.3, and the other was upstream of Husum Falls at rkm 12.3. One of each was near the mouth of the tributaries Mill, Buck, and Rattlesnake Creeks. The loggers were deployed from early June to mid-November and recorded water temperature hourly.

Table 2. Number of steelhead (Oncorhynchus mykiss), Chinook salmon (O. tshawytscha), and coho salmon (O. kisutch), by life-stage, captured, tagged with Passive Integrated Transponder (PIT) tags, and sampled for genetic material at the smolt trap at river kilometer 2.3, White Salmon River, Washington, March 24-May 28, 2016.

[Species: Gen, fin tissue sample collected for genetic analysis]

\begin{tabular}{|c|c|c|c|c|c|c|c|c|c|}
\hline \multirow{3}{*}{ Life stage } & \multicolumn{9}{|c|}{ Species } \\
\hline & \multicolumn{3}{|c|}{ Steelhead } & \multicolumn{3}{|c|}{ Chinook salmon } & \multicolumn{3}{|c|}{ Coho salmon } \\
\hline & Captured & $\begin{array}{c}\text { PIT } \\
\text { tagged }\end{array}$ & Gen & Captured & $\begin{array}{c}\text { PIT } \\
\text { tagged }\end{array}$ & Gen & Captured & $\begin{array}{c}\text { PIT } \\
\text { tagged }\end{array}$ & Gen \\
\hline Fry & 9 & - & 4 & 4 & - & 2 & 21 & - & 19 \\
\hline Parr & 23 & 20 & 21 & 0 & 0 & 0 & - & - & - \\
\hline Smolt & 153 & 150 & 149 & 0 & 0 & 0 & 82 & 79 & 79 \\
\hline
\end{tabular}

\section{Results}

\section{Smolt Trapping Results}

We captured steelhead, coho salmon, and Chinook salmon in the screw trap at rkm 2.3 (figs. 2 and 3; table 2). Steelhead were the most common species captured, with 153 smolts, 23 parr, and 9 fry. Coho were less abundant, with 82 smolts and 21 fry captured. Chinook salmon were rare, with only four fry captured. The smolt migrant estimate was 3,851 (95\% CI = 1,001-6,700; table 3$)$ for steelhead and 1,093 (95 percent CI = 286-1,900; table 3) for coho salmon. We were not able to generate an estimate for fry of any species due to the low numbers captured.

Both steelhead smolts and parr and coho smolts were captured from the beginning of trapping and were still being caught at the end of the trapping period. Weekly counts of steelhead smolts peaked at the end of April (fig. 2) and slowly decreased toward the end of May. Steelhead parr were captured at a relatively steady rate through the trapping period. Weekly counts of coho smolts peaked around the second and third week of May, and coho smolts were still being caught at the end of the trapping period (fig. 3). Capture of steelhead and coho salmon fry increased during the latter one-half of our trapping period. 

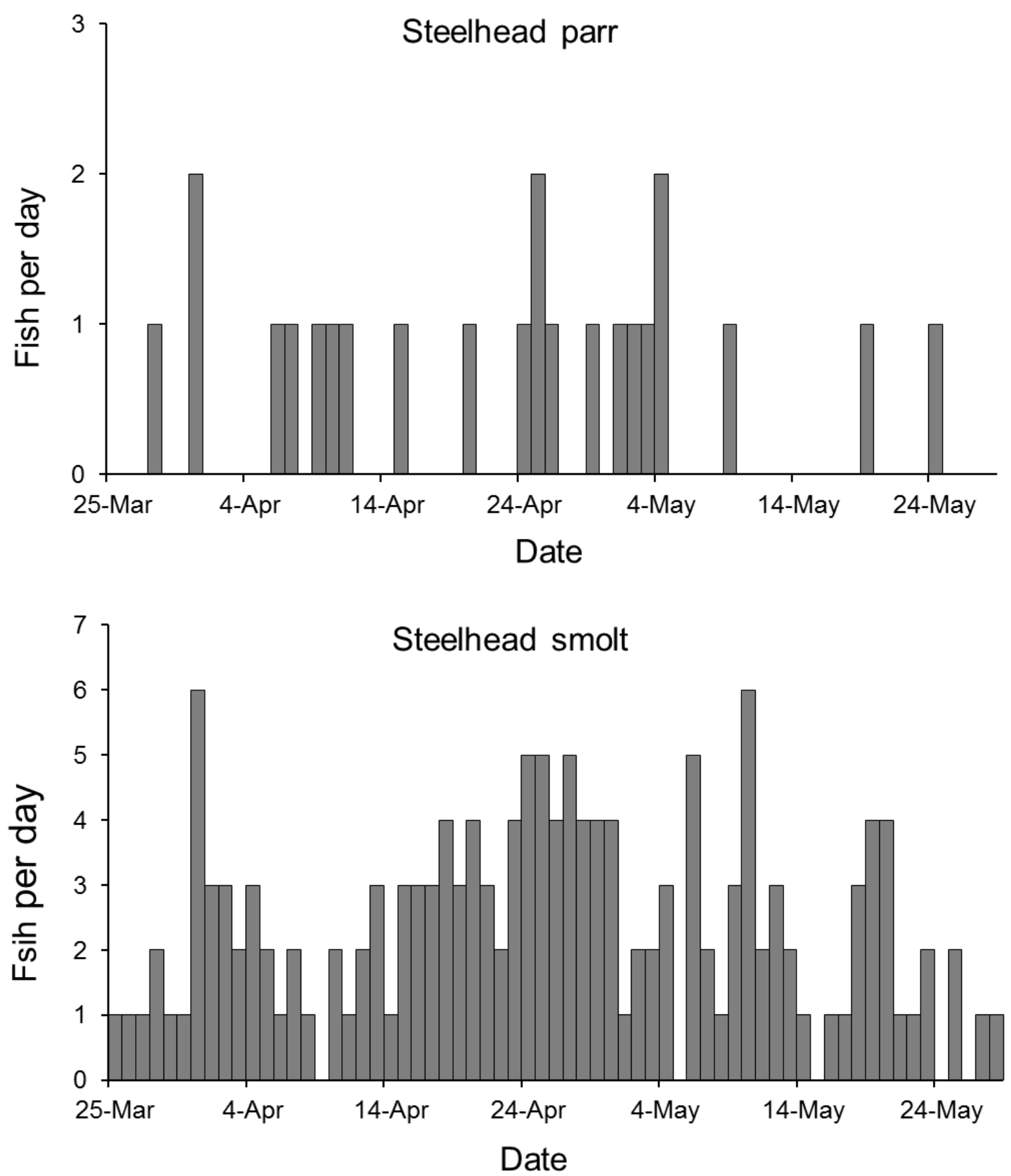

Figure 2. Graphs showing daily catch of steelhead (Oncorhynchus mykiss) parr (upper graph) and smolts (lower graph) in the screw trap at river kilometer 2.3, White Salmon River, Washington, March 24-May 28, 2016. Note that the $y$ axis differs. 


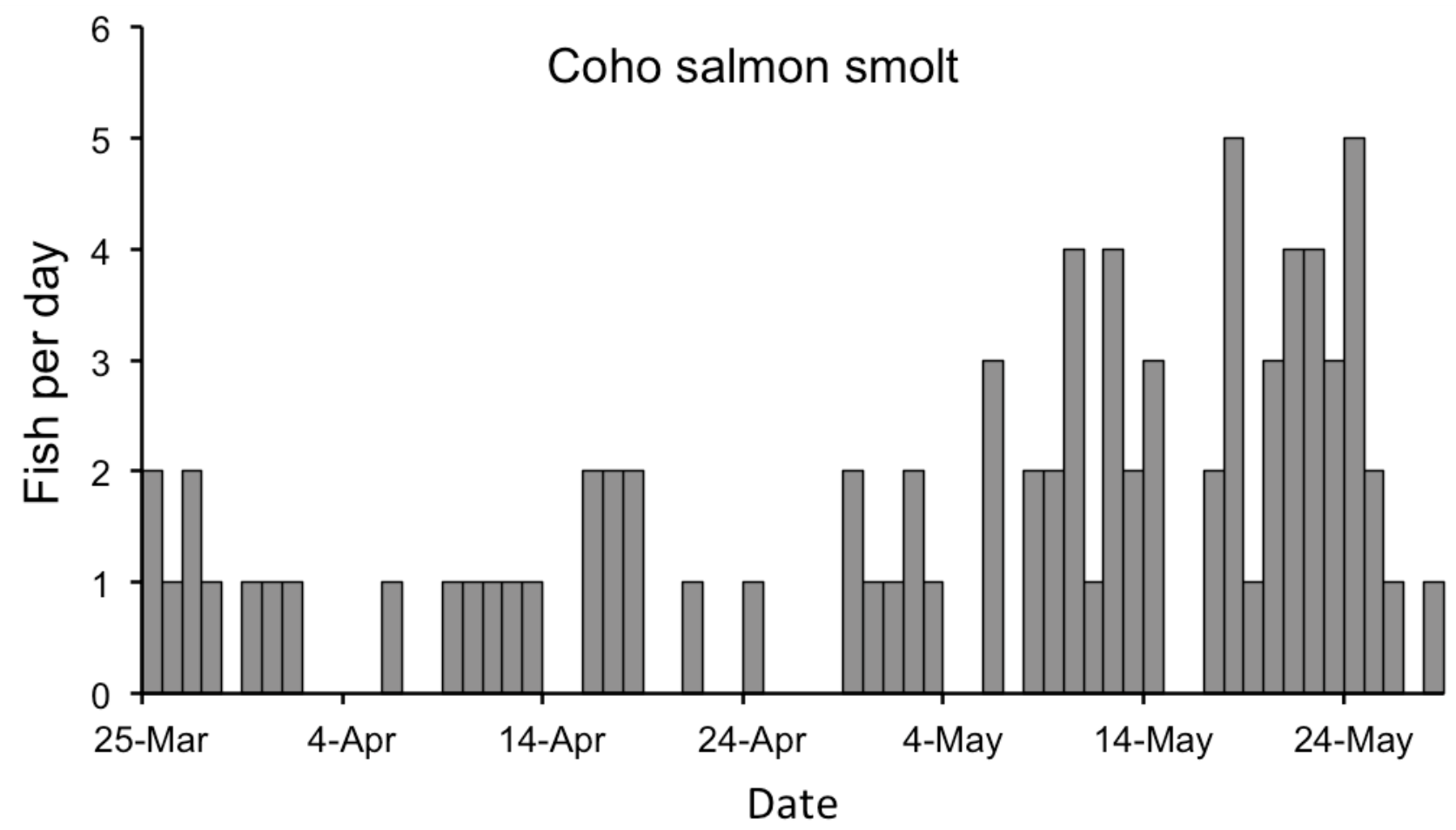

Figure 3. Graph showing daily catch of coho salmon (Oncorhynchus kisutch) smolts in the screw trap at river kilometer 2.3, White Salmon River, Washington, March 24-May 28, 2016.

Table 3. Estimates of steelhead (Oncorhynchus mykiss) smolt and coho salmon (O. kisutch) smolt passage at the smolt trap at river kilometer 2.3, White Salmon River, Washington, March 24-May 28, 2016.

[SE, standard error; CI, confidence interval]

\begin{tabular}{lcccccc}
\hline \multicolumn{1}{c}{ Species } & $\begin{array}{c}\text { Number } \\
\text { captured }\end{array}$ & $\begin{array}{c}\text { Number } \\
\text { marked }\end{array}$ & $\begin{array}{c}\text { Number } \\
\text { recaptured }\end{array}$ & Estimate & SE & $95 \% \mathrm{Cl}$ \\
\hline Steelhead & 153 & 150 & 5 & 3,851 & 1,454 & $1,001-6,700$ \\
Coho salmon & 82 & 79 & 5 & 1,093 & 412 & $286-1,900$ \\
\hline
\end{tabular}

The number of age- 1 or older steelhead and coho captured at the screw trap at rkm 2.3 during 2016 exceeded the number of age-1 or older wild steelhead and coho reported each year from 2007 through 2009 by Allen and Connolly (2011) in a screw trap at rkm 1.5, although they did catch more age-1 or older Chinook salmon. They trapped for a longer time period (early March through late June), but did not fish every day ( $2007=79$ days, $2008=68$ days, $2009=59$ days). They also fished during 2006, but only for 22 days. Because they did not fish the trap every day, they did not generate migrant estimates. Their reported catches during 2007-09 of age- 1 or older wild steelhead were 92, 77, and 47, respectively, and catch of age-1 or older wild coho were 0,20 , and 17 , respectively. Our catch of age- 1 or older steelhead during 2016 (62 days trapping) was 176 and catch of age-1 or older coho was 82 . During 2016, we caught no age-1 or older Chinook salmon. Allen and Connolly (2011) reported 11, 2, and 3 age-1 or older Chinook salmon at the trap in 2007-09, respectively. 
During 2006 through 2009, Allen and Connolly (2011) caught somewhat greater numbers of age- 0 fish. In contrast to the few age-0 Chinook salmon that we caught in $2016(n=4)$, Allen and Connolly (2011) caught many age-0 Chinook salmon during sampling from 2006 to 2009 (range 1,0709,942). They also caught more age-0 steelhead (range 4-54), and age-0 coho (range 62-195), although the differences were not as substantial.

None of the juvenile steelhead or coho salmon caught in the screw trap appeared to be of hatchery origin (based on adipose fin presence and lack of fin erosion), although we did capture one steelhead kelt on March 29, 2016, that was a hatchery fish (lacked adipose fin). We PIT tagged 150 steelhead smolts and 20 steelhead parr. Of the PIT-tagged smolts, 28 were detected passing Bonneville Dam or at the estuary trawl during spring 2016. We also PIT tagged 79 coho salmon smolts, 18 of which were detected at Bonneville Dam during spring 2016.

\section{Electrofishing Results}

\section{Electrofishing Distribution Results}

During electrofishing sampling in 2016, we found juvenile $O$. mykiss at every sample site. Juvenile coho salmon were found at rkm 2.3 of the mainstem White Salmon River, and in Mill and Buck Creeks (tables 4 and 5), which is the first documentation of juvenile coho in the White Salmon watershed upstream of the former Condit Dam site. Additionally, cutthroat trout were found in Mill and Rattlesnake Creeks (tables 4 and 5). We found no juvenile Chinook salmon at any of our electrofishing sample sites during 2016. Although parental origin (anadromous versus resident) of the $O$. mykiss found through the watershed cannot be known instantaneously, we did archive genetic samples from many of these fish $(n=200)$ and the WSTWG will pursue genetic analysis of these samples to investigate parental origin and relatedness to the $O$. mykiss captured at the screw trap. We also PIT tagged many $O$. mykiss during electrofishing surveys $(n=245)$. Future recaptures or detections downstream of these fish will help inform us about anadromy and diversity of life histories of $O$. mykiss throughout the watershed.

Table 4. Presence and absence of steelhead/rainbow trout (Oncorhynchus mykiss), Chinook salmon (O. tshawytscha), coho salmon (O. kisutch), and cutthroat trout (O. clarki clarki) at electrofishing sites in the White Salmon River subbasin, Washington, summer 2016.

[Site start: Rkm denotes river kilometer from mouth. Species: Sth/Rbt, O. mykiss steelhead or rainbow trout; A, absent P, present. m, meter]

\begin{tabular}{lrrcccc}
\hline \multirow{2}{*}{ Site } & Site & Sample & \multicolumn{4}{c}{ Species } \\
\cline { 4 - 7 } & $\begin{array}{c}\text { start } \\
\text { (rkm) }\end{array}$ & $\begin{array}{l}\text { length } \\
(\mathbf{m})\end{array}$ & Sth/Rbt & $\begin{array}{c}\text { Chinook } \\
\text { salmon }\end{array}$ & $\begin{array}{c}\text { Coho } \\
\text { salmon }\end{array}$ & Cutthroat \\
\hline White Salmon River & 2.3 & 260 & $\mathrm{P}$ & $\mathrm{A}$ & $\mathrm{P}$ & $\mathrm{A}$ \\
White Salmon River & 12.3 & 135 & $\mathrm{P}$ & $\mathrm{A}$ & $\mathrm{A}$ & $\mathrm{A}$ \\
Mill Creek & 0.0 & 250 & $\mathrm{P}$ & $\mathrm{A}$ & $\mathrm{P}$ & ${ }^{1} \mathrm{P}$ \\
Mill Creek & 0.5 & 60 & $\mathrm{P}$ & $\mathrm{A}$ & $\mathrm{P}$ & $\mathrm{P}$ \\
Buck Creek & 2.0 & 190 & $\mathrm{P}$ & $\mathrm{A}$ & $\mathrm{P}$ & $\mathrm{A}$ \\
Rattlesnake Creek & 0.3 & 300 & $\mathrm{P}$ & $\mathrm{A}$ & $\mathrm{A}$ & $\mathrm{P}$ \\
Rattlesnake Creek & 2.8 & 250 & $\mathrm{P}$ & $\mathrm{A}$ & $\mathrm{A}$ & $\mathrm{A}$ \\
\hline
\end{tabular}

${ }^{1}$ One fish may have been a rainbow cutthroat hybrid. 
Table 5. Number of juvenile salmonids encountered and tagged with Passive Integrated Transponder (PIT) tags, and from which a tissue sample was collected for genetic analysis during electrofishing surveys in the White Salmon River watershed, Washington, 2016.

[Species: Sth/Rbt, O. mykiss steelhead or rainbow trout; Trout, trout fry that could not be differentiated between cutthroat or O. mykiss. Gen: Fin tissue collected for genetic analysis. $\geq$, greater than or equal to; rkm, river kilometer; m, meter; yr, year]

\begin{tabular}{|c|c|c|c|c|c|c|c|c|}
\hline Site & Dates & $\begin{array}{l}\text { Site } \\
\text { start } \\
(\mathrm{rkm}) \\
\end{array}$ & $\begin{array}{c}\text { Sampled } \\
\text { length } \\
(\mathrm{m})\end{array}$ & Species & $\begin{array}{l}\text { Age } \\
\text { (yr) }\end{array}$ & Catch & $\begin{array}{c}\text { PIT } \\
\text { tagged }\end{array}$ & Gen \\
\hline White Salmon River & $08-02-2016$ & 2.3 & 260 & $\mathrm{Sth} / \mathrm{Rbt}$ & 0 & 10 & 0 & 3 \\
\hline White Salmon River & $08-02-2016$ & 2.3 & 260 & $\mathrm{Sth} / \mathrm{Rbt}$ & $\geq 1$ & 15 & 14 & 10 \\
\hline White Salmon River & 08-02-2016 & 2.3 & 260 & Coho & 0 & 2 & 1 & 1 \\
\hline White Salmon River & 08-03-2016 & 12.3 & 135 & $\mathrm{Sth} / \mathrm{Rbt}$ & 0 & 23 & 2 & 15 \\
\hline White Salmon River & 08-03-2016 & 12.3 & 135 & $\mathrm{Sth} / \mathrm{Rbt}$ & $\geq 1$ & 7 & 7 & 6 \\
\hline Mill Creek & $07-25-2016$ & 0.0 & 250 & Trout & 0 & 141 & 10 & 14 \\
\hline Mill Creek & $07-25-2016$ & 0.0 & 250 & $\mathrm{Sth} / \mathrm{Rbt}$ & $\geq 1$ & 27 & 25 & 8 \\
\hline Mill Creek & $07-25-2016$ & 0.0 & 250 & Cutthroat & $\geq 1$ & 1 & 1 & 1 \\
\hline Mill Creek & $07-25-2016$ & 0.0 & 250 & Coho & 0 & 7 & 1 & 5 \\
\hline Mill Creek & $08-08-2016$ & 0.5 & 60 & Trout & 0 & 25 & 1 & 6 \\
\hline Mill Creek & $08-08-2016$ & 0.5 & 60 & $\mathrm{Sth} / \mathrm{Rbt}$ & $\geq 1$ & 6 & 5 & 5 \\
\hline Mill Creek & $08-08-2016$ & 0.5 & 60 & Cutthroat & $\geq 1$ & 7 & 7 & 6 \\
\hline Mill Creek & 08-08-2016 & 0.5 & 60 & Coho & 0 & 35 & 13 & 10 \\
\hline Buck Creek & $07-28,29-2016$ & 2.0 & 190 & $\mathrm{Sth} / \mathrm{Rbt}$ & 0 & 224 & 6 & 15 \\
\hline Buck Creek & $07-28,29-2016$ & 2.0 & 190 & $\mathrm{Sth} / \mathrm{Rbt}$ & $\geq 1$ & 56 & 55 & 37 \\
\hline Buck Creek & $07-28,29-2016$ & 2.0 & 190 & Coho & 0 & 55 & 23 & 26 \\
\hline Rattlesnake Creek & $07-26,27-2016$ & 0.3 & 200 & Trout & 0 & 260 & 29 & 28 \\
\hline Rattlesnake Creek & $07-26,27-2016$ & 0.3 & 200 & $\mathrm{Sth} / \mathrm{Rbt}$ & $\geq 1$ & 10 & 10 & 3 \\
\hline Rattlesnake Creek & $07-26,27-2016$ & 0.3 & 200 & Cutthroat & $\geq 1$ & 3 & 3 & 3 \\
\hline Indian Creek & $07-27-2016$ & 0.0 & 50 & Trout & 0 & 20 & 0 & 15 \\
\hline Rattlesnake Creek & $10-19-2016$ & 0.4 & 200 & Trout & 0 & 213 & 39 & 0 \\
\hline Rattlesnake Creek & $10-19-2016$ & 0.4 & 200 & $\mathrm{Sth} / \mathrm{Rbt}$ & $\geq 1$ & 11 & 11 & 0 \\
\hline Rattlesnake Creek & 09-01-2016 & 2.8 & 250 & $\mathrm{Sth} / \mathrm{Rbt}$ & 0 & 19 & 12 & 19 \\
\hline Rattlesnake Creek & 09-01-2016 & 2.8 & 250 & $\mathrm{Sth} / \mathrm{Rbt}$ & $\geq 1$ & 19 & 19 & 16 \\
\hline
\end{tabular}




\section{Electrofishing Abundance Results}

We generated abundance estimates for age- 0 and age- 1 and older salmonids in sections of Buck and Rattlesnake Creeks during summer 2016 (figs. 4 and 5; table 6). Both sites had been sampled prior to removal of Condit Dam (Allen and others, 2003a, 2003b; Allen, Connolly, Jezorek, and others, 2006; Allen, Connolly, Munz, and others, 2006; Allen and others, 2012). Abundance of age-0 O. mykiss at our sample site in Buck Creek during 2016 was $3.0 \mathrm{fish} / \mathrm{m}$ (standard error [SE] = 0.45) and was 3.6 fish $/ \mathrm{m}$ $(\mathrm{SE}=0.56)$ at our sample site in Rattlesnake Creek. Age-0 O. mykiss were more abundant at the Buck Creek site during 2016 than during either 2009 (1.6 fish/m) or 2010 (1.9 fish/m), as reported by Allen and others (2012). Age-0 O. mykiss in the Rattlesnake Creek site were more abundant than in 3-5 years monitored prior to Condit Dam removal (2001-05; mean abundance $=3.4 \mathrm{fish} / \mathrm{m}$, range $=1.5-5.1$ fish/m; Allen and others 2003a, 2003b; Allen, Connolly, Jezorek, and others, 2006; Allen, Connolly, Munz, and others, 2006). Abundance of age-0 coho salmon at the Buck Creek site during 2016 was 0.5 fish/m $(\mathrm{SE}=0.10)$. No coho were found at the Rattlesnake Creek site.

Abundance of age-1 and older O. mykiss at our sample site in Buck Creek was $0.6 \mathrm{fish} / \mathrm{m}(\mathrm{SE}=$ 0.12), which was similar to results in $2009(0.58 \mathrm{fish} / \mathrm{m})$ and $2010(0.61 \mathrm{fish} / \mathrm{m})$, as reported by Allen and others (2012). Abundance of age-1 and older $O$. mykiss at our sample site in Rattlesnake Creek was $0.1 \mathrm{fish} / \mathrm{m}(\mathrm{SE}=0.03$; figs. 4 and 5 ; table 6$)$, which was less than in any years monitored prior to Condit Dam removal (2000-05; mean abundance $=0.5 \mathrm{fish} / \mathrm{m}$, range $=0.3-0.8 \mathrm{fish} / \mathrm{m}$; Allen and others 2003a, 2003b; Allen, Connolly, Jezorek, and others, 2006; Allen, Connolly, Munz, and others, 2006).

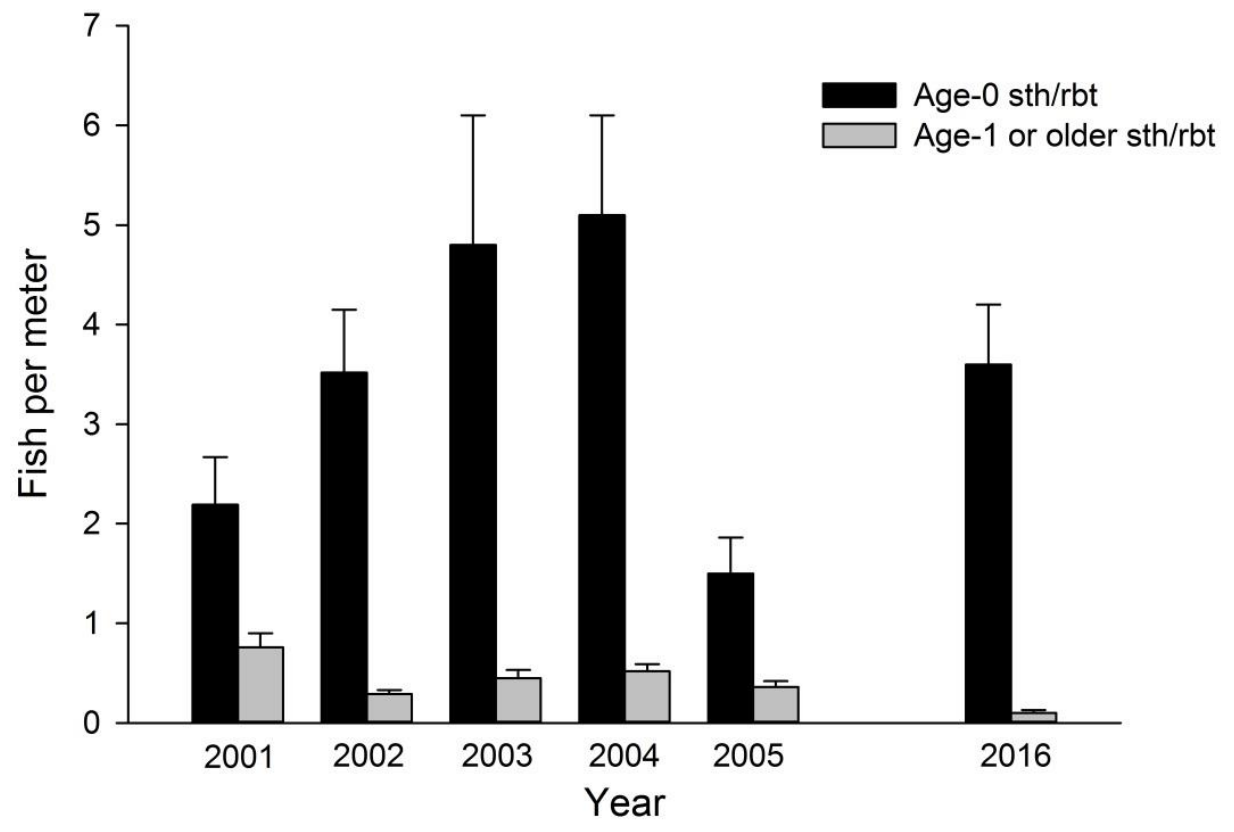

Figure 4. Graph showing abundance estimates (fish per meter) of steelhead/rainbow trout (sth/rbt) (Oncorhynchus mykiss) at a site in the lower kilometer of Rattlesnake Creek, Washington. Estimates are shown for 5 years prior to removal of Condit Dam from the White Salmon River (breached in 2011) and during 2016. Error bars indicate standard error. 


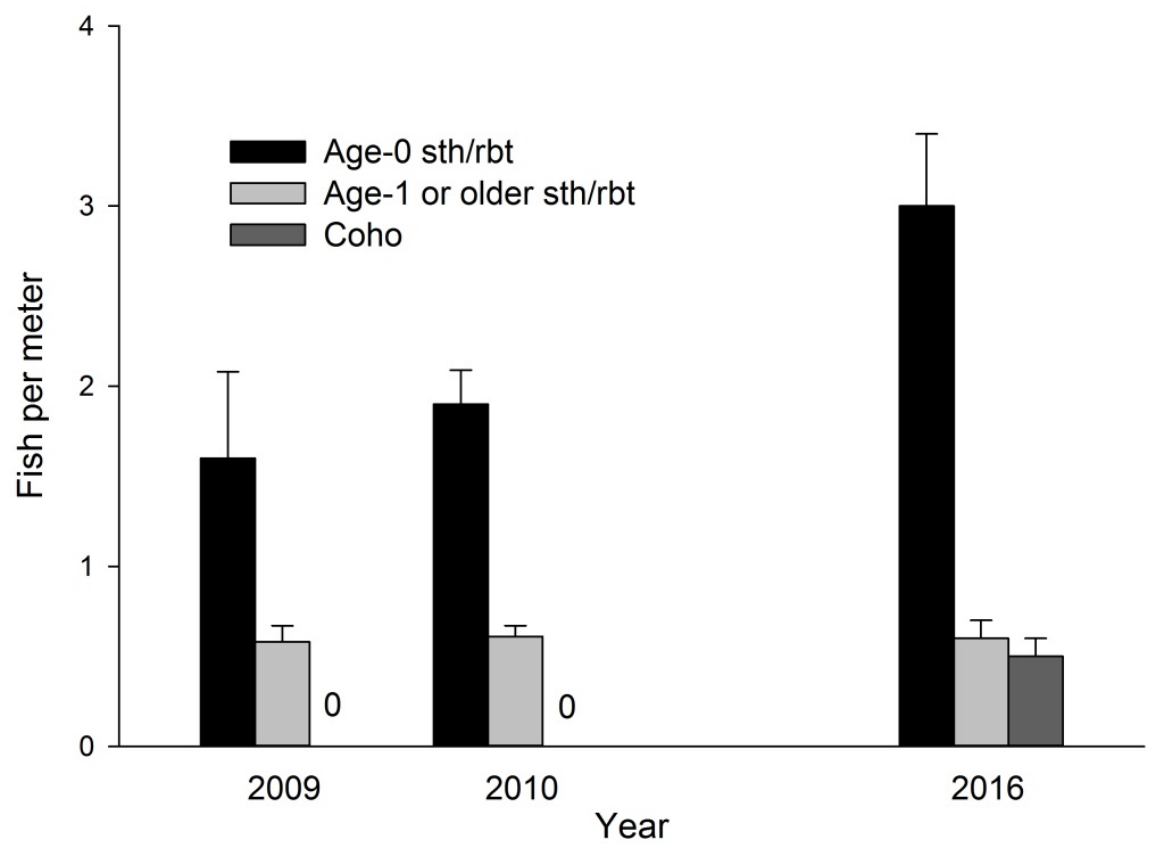

Figure 5. Graph showing abundance estimates (fish per meter) of steelhead/rainbow trout (sth/rbt) (Oncorhynchus mykiss) and coho salmon (O. kisutch) at a sample site at river kilometer 2.0, Buck Creek, Washington. Estimates are shown for 2 years prior to removal of Condit Dam from the White Salmon River (breached in 2011) and during 2016. Error bars indicate standard error.

Table 6. Population estimates and standard error (SE), abundance (fish per meter), and density (fish per meter squared) of steelhead/rainbow trout (Oncorhynchus mykiss) and coho salmon (O. kisutch) at abundance electrofishing sites in Buck and Rattlesnake Creeks, July 2016.

[Site and species: $\mathrm{Sth} / \mathrm{Rbt}, O$. mykiss steelhead or rainbow trout. SE, standard error. $\mathrm{m}$, meter; $\mathrm{m}^{2}$, square meter; yr, year; $\geq$, greater than or equal to]

\begin{tabular}{|c|c|c|c|c|c|c|c|c|}
\hline $\begin{array}{c}\text { Site } \\
\text { and species }\end{array}$ & $\begin{array}{c}\text { Age } \\
\text { (yr) }\end{array}$ & $\begin{array}{l}\text { Number } \\
\text { marked }\end{array}$ & $\begin{array}{l}\text { Number } \\
\text { captured }\end{array}$ & $\begin{array}{c}\text { Number } \\
\text { recaptured }\end{array}$ & $\begin{array}{c}\text { Abundance } \\
\text { estimate }\end{array}$ & SE & $\mathrm{Fish} / \mathrm{m}$ & $\mathrm{Fish} / \mathrm{m}^{2}$ \\
\hline \multicolumn{9}{|l|}{ Buck Creek } \\
\hline Sth/Rbt & 0 & 113 & 128 & 25 & 566 & 85.5 & 3.0 & 0.37 \\
\hline Sth/Rbt & $\geq 1$ & 33 & 31 & 9 & 109 & 22.9 & 0.6 & 0.07 \\
\hline Coho & 0 & 35 & 29 & 10 & 98 & 18.8 & 0.5 & 0.06 \\
\hline \multicolumn{9}{|c|}{ Rattlesnake Creek } \\
\hline $\mathrm{Sth} / \mathrm{Rbt}$ & 0 & 125 & 149 & 25 & 727 & 113.3 & 3.6 & 0.46 \\
\hline $\mathrm{Sth} / \mathrm{Rbt}$ & $\geq 1$ & 7 & 3 & 1 & 16 & 5.7 & 0.1 & 0.01 \\
\hline
\end{tabular}




\section{Water Temperature Results}

Water temperature in the mainstem White Salmon River remained cold through the summer at both of our monitoring locations (table 7), but warmer in the tributaries. In the White Salmon River, maximum temperature from June through October at rkm 12.3 was $10.7^{\circ} \mathrm{C}$, and at $\mathrm{rkm} 2.3$ was $15.9^{\circ} \mathrm{C}$. Mill Creek also remained cold with a maximum temperature of $15.4^{\circ} \mathrm{C}$ near the mouth. Buck Creek had slightly higher temperatures, with a maximum water temperature of $17.3{ }^{\circ} \mathrm{C}$ near the mouth. A $16{ }^{\circ} \mathrm{C}$ limit for surface water has been set by the Washington State Department of Ecology as an indicator of stream health for salmonid habitat, and a $20^{\circ} \mathrm{C}$ limit for non-salmonid habitat (Washington State Department of Ecology, 2016). Water temperature in Buck Creek met or exceeded $16^{\circ} \mathrm{C}$ on 6 days in July and 9 days in August. Maximum water temperature in Rattlesnake Creek was $22.8^{\circ} \mathrm{C}$ (recorded in July). Water temperatures in Rattlesnake Creek met or exceeded $16{ }^{\circ} \mathrm{C}$ on 19 days in June, 31 days in July, 31 days in August, and 10 days in September.

Table 7. Minimum, mean, and maximum water temperature, and number of days when water temperature met or exceeded $16^{\circ} \mathrm{C}$ at five sites in the White Salmon River watershed, Washington, June-October 2016.

[Site: WSR, White Salmon River at raceways; WSH, White Salmon River at Husum; Mill, Mill Creek; Buck, Buck Creek; Rattle, Rattlesnake Creek. $\geq$, greater than or equal to]

\begin{tabular}{llrrrrr}
\hline & & \multicolumn{5}{c}{ Site } \\
\cline { 3 - 7 } & & WSR & WSH & Mill & Buck & Rattle \\
\hline June & & & & & \\
& Minimum & 8.1 & 7.5 & 8.2 & 8.7 & 10.4 \\
& Mean & 10.1 & 9.3 & 11.4 & 12.2 & 15.9 \\
& Maximum & 12.0 & 11.4 & 14.9 & 15.9 & 21.8 \\
& Days $\geq 16^{\circ} \mathrm{C}$ & 0 & 0 & 0 & 0 & 19
\end{tabular}

July

$\begin{array}{lccccl}\text { Minimum } & 10.4 & 8.5 & 10.5 & 11.5 & 14.7 \\ \text { Mean } & 11.8 & 9.5 & 12.4 & 13.9 & 18.0 \\ \text { Maximum } & 14.0 & 10.7 & 15.4 & 17.3 & 22.8 \\ \text { Days } \geq 16^{\circ} \mathrm{C} & 0 & 0 & 0 & 6 & 31\end{array}$

August

$\begin{array}{lccccl}\text { Minimum } & 12.8 & 8.4 & 11.0 & 11.9 & 13.8 \\ \text { Mean } & 14.4 & 9.3 & 12.8 & 14.4 & 17.9 \\ \text { Maximum } & 15.9 & 10.3 & 14.5 & 17.0 & 21.6 \\ \text { Days } \geq 16^{\circ} \mathrm{C} & 0 & 0 & 0 & 9 & 31\end{array}$

September

$\begin{array}{lccccc}\text { Minimum } & 11.5 & 7.7 & 9.6 & 9.3 & 9.9 \\ \text { Mean } & 13.2 & 8.4 & 11.2 & 12.0 & 14.0 \\ \text { Maximum } & 14.8 & 9.2 & 13.3 & 13.9 & 17.2 \\ \text { Days } \geq 16^{\circ} \mathrm{C} & 0 & 0 & 0 & 0 & 10\end{array}$

October

\begin{tabular}{lccccc} 
Minimum & 8.0 & 7.2 & 7.5 & 7.3 & 7.5 \\
Mean & 9.9 & 8.1 & 9.7 & 10.0 & 11.1 \\
Maximum & 13.2 & 8.9 & 11.2 & 12.2 & 14.4 \\
Days $\geq 16^{\circ} \mathrm{C}$ & 0 & 0 & 0 & 0 & 0 \\
\hline
\end{tabular}




\section{Discussion}

Juvenile salmonid sampling in the White Salmon River during 2016 demonstrated that steelhead and coho smolts are originating upstream of rkm 2.3 and produced the first estimates of smolt abundance since Condit Dam was breached in 2011. It is likely that many of these smolts originated from fish that spawned upstream of the former Condit Dam site. Sampling in Mill, Buck, and Rattlesnake Creeks produced the first juvenile salmonid abundance estimates in tributaries since dam breaching and established that juvenile coho salmon were present in Mill and Buck Creeks during 2016. These data contribute to the work done by the WSTWG to evaluate anadromous salmonid recolonization of the White Salmon River and provide the first data for potential evaluation of juvenile abundance trends in the White Salmon River post dam removal.

We found that smolt trapping was feasible at rkm 2.3, but the precision of estimates was less than desired (coefficient of variation $=38$ percent). Although recapture rates were similar to screw trapping in nearby rivers of similar size (Buehrens and Cochran, 2016; Zendt and others, 2016), the number of fish captured/recaptured was relatively small. Precision of smolt estimates could be improved by several methods to increase the number of fish captured or the trap efficiency. Operation of the trap for a longer duration (begin earlier in March and operate into June) would provide the opportunity to capture more fish. However, during 2016 river flows were consistently high during March making an earlier installation of the trap difficult. A larger trap (2.4-m cone as opposed to the $1.5-\mathrm{m}$ cone) or two traps at rkm 2.3 would likely result in greater fish capture and efficiency. The feasibility of operating a larger trap at the current site would need investigation to ensure adequate depth. Operation of two traps would need to take into consideration recreational boater safety because the White Salmon River is very popular with rafters and kayakers. The two traps could be oriented side-by-side or with one upstream of the other. Operation of another screw trap at a point upstream, or traps or weirs in Mill, Buck, or Rattlesnake Creeks would increase the number of marked fish available for recapture. The ESA Recovery Plan for the White Salmon River Watershed (National Marine Fisheries Service, 2013b) suggests operation of weirs or traps at Rattlesnake and Buck Creeks. All the above methods would likely improve the precision of the smolt estimates, but all would substantially increase operating cost. If the number of smolts produced in the White Salmon increases in future years, the number of fish captured and recaptured may increase without changes to trapping scenarios.

The finding that absolute numbers of age- 1 and older steelhead and age- 1 coho captured at the screw trap were greater in 2016 than during 2006-09 (at rkm 1.5) suggests several possibilities since dam removal. This increase could be the result of increased anadromous spawning in the watershed, increased suitable rearing habitat for fry or parr, or an increase in anadromous life-history expression from O. mykiss in the watershed. Catch of both age-0 steelhead and coho at the screw trap in 2006-09 was slightly greater each year than in 2016. Because any steelhead or coho salmon that spawned in the White Salmon River prior to 2012 had to do so downstream of Condit Dam (rkm 5.3), age-0 habitat may have been limiting resulting in downstream displacement. Particularly, the reach of the White Salmon between the Condit Dam and the Powerhouse at rkm 3.0 experienced varied and reduced flow due to routing of water through the pipe to the Powerhouse, which may have displaced fish. 
We caught far fewer Chinook salmon fry in the screw trap than during 2006-09. During that period, the screw trap was located farther downstream (rkm 1.5), and most fall Chinook salmon spawning occurs between there and the current trap location (rkm 2.3). However, fall Chinook salmon do spawn upstream of rkm 2.3 as well as the majority of spring Chinook salmon. During fall 2015, the estimate of fall Chinook spawners upstream of rkm 2.3 was 3,158, of which 90 percent were upriver Bright-stock Chinook salmon (Jeremy Wilson, Washington Department of Fish and Wildlife, written commun., 2016). An additional 91 and 151 spring Chinook salmon spawners in 2015 and 2014, respectively, were estimated upstream of rkm 2.3. To date, no assessment of Chinook salmon adult-tojuvenile recruitment has occurred in the White Salmon River.

A substantial flood occurred in the White Salmon River in December 2015 (estimated at a 25year interval event). This flood, combined with the dynamic nature of much of the substrate in the river both upstream and downstream of the dam site, may have resulted in high egg-to-fry mortality due to bed scour and subsequent redd destruction. However, with only 1 year of data, we do not know if this was the case, or if Chinook salmon that spawn upstream of our screw trap site are frequently unsuccessful. Work by Allen and Connolly (2011) and Smith and Engle (2011) showed that Tule Chinook salmon spawning was more successful than upriver Bright Chinook salmon spawning in the White Salmon River during 2006 through 2008.

No juvenile Chinook salmon were found in our electrofishing samples during 2016, despite reported spawning upstream of rkm 2.3 and spring Chinook salmon adults reported upstream of Husum Falls in 2014. Both spring and fall Chinook salmon were reported spawning upstream of rkm 2.3 during 2016 and spring Chinook salmon were reported spawning upstream of Husum Falls. Continued screw trapping and electrofishing will provide a better understanding of distribution and juvenile recruitment from Chinook salmon spawning in the White Salmon River.

The presence of juvenile coho in Mill Creek (to at least rkm 0.5) and Buck Creek (to at least rkm 2.2) suggest coho are spawning in these tributaries. We PIT tagged juvenile coho in both tributaries and further monitoring is necessary to assess outmigration and adult return. Coho spawning frequency and juvenile use of the mainstem White Salmon River are not known. It is assumed that Husum Falls is a barrier to adult coho, but further sampling may be necessary to assess and confirm coho distribution in the mainstem and tributaries. We found no juvenile coho in Rattlesnake Creek or a short section of Indian Creek. We do not know if adult coho avoided Rattlesnake Creek, spawned there but experienced fry mortality, or spawned successfully but juveniles outmigrated prior to our late July sampling. The low flow and high water temperature in Rattlesnake Creek could have been a less hospitable for juvenile coho than Mill or Buck Creeks. Rattlesnake Creek is the most upstream of these tributaries and adult coho could be opportunistically using the first suitable tributaries they encounter. If adult coho abundance increases in the White Salmon Watershed, they may use all available habitats.

The fewer age-1 or older O. mykiss in Rattlesnake Creek in 2016 than found during pre-dam removal surveys is interesting considering that age-1 O. mykiss abundance in Buck Creek was similar to pre-dam removal estimates. Additionally, 2016 age-0 abundance in both creeks was somewhat greater than average age- 0 abundance pre-dam removal. Counts of possible and probable redds were similar between 2015 and 2016 in both Buck and Rattlesnake Creeks (Joe Zendt, Yakama Nation Fisheries, written commun., 2016). Buck Creek had a greater number of possible and probable redds counted each year, but they were spread over a longer section of stream. The juvenile abundance data from summer 2016 suggest a lower rate of recruitment of age-1 O. mykiss per spawner from 2015 at our site in Rattlesnake Creek compared to Buck Creek. Longer term data are required to properly evaluate whether this is a unique or common occurrence. Conditions in Rattlesnake Creek would likely have been very poor during summer 2015, when the Pacific Northwest suffered a very warm and dry summer. 
According to the National Drought Mitigation Center, southwestern Washington was in a state of Extreme Drought during summer 2015. Age-0 O. mykiss that may have been present in Rattlesnake Creek at that time could have suffered mortality or outmigrated to the White Salmon River. It is also possible that age-0 to age-1 survival of $O$. mykiss in Rattlesnake Creek is currently very poor. Additional years of sampling may be necessary to assess this relationship.

Events such as the dry summer of 2015 and the large flood of December 2015 affect different life stages of different species and affect the variability of fish populations even under static habitat conditions. Currently, the mainstem White Salmon River is still a dynamic environment following the removal of Condit Dam and redistribution of sediments. The many possible limiting factors by lifestage, species, and cohort in the watershed cannot be addressed with 1 year of study of either adults or juveniles. A single year of monitoring any restoration action gives important but limited information. Long term trend analysis is required to reach firm conclusions about efficacy of restoration (Kondolf, 2007; Brewitt, 2016). Studies of restoration projects that are of short duration could even result in premature and erroneous conclusions (Herrick and others, 2006). Pess (2009) reported that 20-25 years may be required to restore salmonid populations following dam removal highlighting the need for longer term studies.

Adult anadromous fish are spawning in the areas of the White Salmon River watershed made accessible by the removal of Condit Dam. Much remains to be learned about the origin of these adults and their spawning success. Juvenile fish are being produced, but their parental origin and relationship to listed stocks is unknown, particularly with steelhead O. mykiss in the basin. A management concern is the potential influence of hatchery-origin spawners on an attempt to naturally reestablish a sustainable wild population. The methods employed during 2016 provided an opportunity to PIT tag fish and archive genetics samples. The WSTWG is exploring options for analyzing the genetics samples. White Salmon River steelhead are currently in the East Cascades MPG of the MCR DPS. We hope to analyze the genetic samples collected to determine relatedness to resident stocks previously sampled upstream of the dam or to hatchery or wild steelhead that may be straying into the White Salmon and spawning. Data from PIT-tagged fish will contribute to understanding of life-history diversity (for example, are the steelhead summer or winter run, are resident $O$. mykiss re-expressing anadromy?) and will help determine if juveniles are returning as viable adults.

We hope the juvenile salmonid data collected in the White Salmon River watershed during 2016 can be a starting point for a longer term monitoring program in concert with other efforts by the WSTWG. These data can be of use in establishing some spawner/smolt relationships and provide a basis for assessing changes in distribution and spawning success as fisheries trend data are gathered following this major dam removal. These data will also provide managers information on VSP parameters needed to evaluate health of stocks of ESA listed fish. The removal of Condit Dam on the White Salmon River reopened a significant amount of habitat for populations of Chinook salmon and coho salmon in the gorge strata of the LCR ESU and for steelhead in the East Cascades MPG of the MCR DPS. The descriptive data collected from juvenile and adult salmonids in the White Salmon watershed will help managers evaluate dam removal efficacy and the natural recolonization strategy, and also evaluate the contribution of anadromous fish in the White Salmon River watershed to strengthening abundance and diversity of ESA listed populations. 


\section{Acknowledgments}

Funding for this project was provided through MCFEG with funds from the Washington State Salmon Recovery Funding Board. We would like to thank Margaret Neuman for her support and tireless efforts to acquire and administer these funds. We thank our fellow USGS employees Sam Doak, Brad Liedtke, Jonathan Schafer, Dennis Sitherwood, and Andy Wells for providing many hours of help in the field and office. Seth Raehsler with MCFEG also provided much field assistance. Jacob Anderson, with Klickitat County, provided support and communication assistance during the proposal process. Thomas Beuhrens and Bryce Glaser of WDFW provided support and feedback for our proposal, and assistance with permitting on short notice, for which we are grateful. Additionally, they provided a tablet field computer for use at our smolt trap site, which saved many hours of manual data entry. Ben Warren and Daniel Warren of WDFW provided us with instruction in using the tablet computer. Larry Zeigenfuss, Joe Skalicky, and Mark Doulos of USFWS provided us with permission to access USFWS property and provided help with deployment and removal of the smolt trap. Joe Zendt and Mike Babcock of Yakama Nation Fisheries Program provided us with PIT tags. We would like to thank the many landowners who provided us access to their property, including PacificCorp, USFS, Washington State Department of Natural Resources, David Crumpacker, Susan and Rainer Hummel, Steve Stampfli, and Terie Tietjen. Brady Allen and Amy Hansen provided reviews that much improved this document. We would also like to thank the technical and citizens committees of the Klickitat Lead Entity and the Lower Columbia Fish Recovery Board, as well as the board members, for their support.

\section{References Cited}

Allen, M.B., and Connolly, P.J., 2005, Assessment of the White Salmon watershed using the ecosystem diagnosis and treatment model- Final Report for the period November 2003 to December 2004: Yakama Nation, Agreement No. BGC045042, 55 p.

Allen, M.B., and Connolly, P.J., 2011, Composition and relative abundance of fish species in the lower White Salmon River, Washington, prior to the removal of Condit Dam: U.S. Geological Survey Open-File Report 2011-1087, 32 p.

Allen, M.B., Connolly, P.J., Jezorek, I.G., Munz, C., and Charrier, J.C., 2006, Assess current and potential salmonid production in Rattlesnake Creek in association with restoration efforts: U.S. Geological Survey 2004-2005 Annual Report, Project No. 200102500, BPA Report DOE/BP00005068-4, 101 p, accessed November 28, 2016, at https://www.cbfish.org/Document.mvc/Viewer/00005068-4.

Allen, M.B., Connolly, P.J., and Martens, K., 2003a, Report A-Characterization of flow, temperature, habitat conditions, and fish populations in the Rattlesnake Creek watershed, in Connolly, P.J., ed., Assess current and potential salmonid production in Rattlesnake Creek associated with restoration efforts: U.S. Geological Survey 2001 Annual Report for Bonneville Power Administration, Project No. 200102500, 65 p., accessed November 28, 2016, at https://www.cbfish.org/Document.mvc/Viewer/00005068-1.

Allen, M.B., Connolly, P.J., and Martens, K., 2003b, Report A-Characterization of flow, temperature, habitat conditions, and fish populations in the Rattlesnake Creek watershed, in Connolly, P.J., ed., Assess current and potential salmonid production in Rattlesnake Creek associated with restoration efforts: U.S. Geological Survey 2002 Annual Report for Bonneville Power Administration, Project No. 200102500, 188 p., accessed November 28, 2016, at https://www.cbfish.org/Document.mvc/Viewer/00005068-2. 
Allen, M.B., Connolly, P.J., Munz, C.S., and Charrier, J.C., 2006, Assess current and potential salmonid production in Rattlesnake Creek in association with restoration efforts: U.S. Geological Survey 2003 Annual Report for Bonneville Power Administration, Project No. 200102500, 128 p., accessed November 28, 2016, at https://www.cbfish.org/Document.mvc/Viewer/00005068-3.

Allen, M.B., Engle, R.O., Zendt, J.S., Shrier, F.C., Wilson, J.T., and Connolly, P.J., 2016, Salmon and steelhead in the White Salmon River after the removal of Condit Dam-Planning efforts and recolonization results: Fisheries, v. 41, p. 190-203.

Allen, M.B., Munz, C., Burkhardt, J., and Connolly, P.J., 2012, Fish Population and habitat analysis in Buck Creek, Washington, prior to recolonization by anadromous salmonids after the removal of Condit Dam: U.S. Geological Survey Open-File Report 2012-1270, 38 p.

Aspect Consulting, 2011, City of White Salmon aquifer storage and recovery feasibility assessment: Prepared for the city of White Salmon, Washington, Project No. 090094-001-01, 130 p.

Bellmore, R.J., Duda, J.J., Craig, L.S., Greene, S.L., Torgersen, C.E., Collins, M.J., and Vittum, K., 2016, Status and trends of dam removal research in the United States: WIREs, v. 4, no. 2, doi: 10.1002/wat2.1164, accessed December 19, 2016, at http://onlinelibrary.wiley.com/doi/10.1002/wat2.1164/abstract.

Brewitt, P.K., 2016, Do the fish return?-A qualitative assessment of anadromous Pacific salmonids' upstream movement after dam removal: Northwest Science, v. 90, p. 433-449.

Buehrens, T., and Cochran, P., 2016, Abundance and productivity of Wind River steelhead and preliminary assessment of their response to Hemolock Dam removal, 2014: Washington Department of Fish and Wildlife Annual Report, Project Number 1998-019-00, BPA Report, accessed December 20, 2016, at https://www.cbfish.org/Document.mvc/Viewer/P149707.

Columbia Basin Fish and Wildlife Authority, 2014, PIT Tag Marking Procedures Manual: Portland, Oregon, PIT Tag Steering Committee, 34 p., accessed December 17, 2016, at www.ptagis.org/docs/defoult-source/ptagis-program-documents/2014-mark-proceduresmanual.pdf? sfvrsn=2.

Connolly, P.J., and Brenkman, S.J., 2008, Fish assemblage, density, and growth in lateral habitats within natural and regulated sections of Washington's Elwha River prior to dam removal: Northwest Science, v. 82, p. 107-118.

Cowan, B., 1999, WRIA 29 Salmonid habitat limiting factors analysis report: Olympia, Washington, Washington Conservation Commission, 98 p.

Crawford, B.A., and Rumsey, S.M., 2011, Guidance for monitoring recovery of Pacific Northwest salmon and steelhead listed under the endangered species act: National Oceanic and Atmospheric Administration, National Marine Fisheries Service, Northwest Region, Portland, Oregon, 160 p., accessed December 12, 2016, at http://www.westcoast.fisheries.noaa.gov/publications/recovery_planning/salmon_steelhead/domains/r me-guidance.pdf.

Dammerman, K., Hand, D., Olson, D., Poirier, J., Pastor, S. and Rivera, J., 2016, Monitoring and evaluation updates for John Day / The Dalles Dam mitigation programs at Spring Creek and Little White Salmon National Fish Hatcheries-2016 Annual Report: U.S. Fish and Wildlife Service, accessed December 13, 2016, at https://www.fws.gov/columbiariver/publications/JDM\%20Report_USACE_Dammerman\%20et\%20al $\% 20$ Oct $\% 202016$.pdf. 
Greenworks, Kleinfelder, and JR Merit Industrial Contractors, 2011, Revegetation and wetlands management plan: Prepared for PacifiCorp, Condit Hydroelectric Project Decommissioning FERC Project No. 2342, 48 p.

Gregory, S., Li, H., and Li, J., 2002, The conceptual basis for ecological responses to dam removal: BioScience, v. 52, p. 713-723.

Hardiman, J.M., and Allen, M.B., 2015, Salmon habitat assessment for conservation planning in the lower White Salmon River, Washington: U.S. Geological Survey Open-File Report 2015-1100, 24 p.

Haring, D., 2003, Addendum to wind/white salmon Water Resource Inventory Area 29 salmonid habitat limiting factor analysis (originally issued July 1999): Washington Conservation Commission, 98 p.

Hart, D.D., Johnson, T.E., Bushaw-Newton, K.L., Horwithz, R.J., Benarek, A.T., Charles, D.F., Kreeger, D.A., and Velinsky, D.J., 2002, Dam removal—Challenges and opportunities for ecological research and river restoration: BioScience v. 52, p. 669-681.

Hatten, J.R., Batt, T.R., Skalicky, J.J., Engle, R. Barton, G.J., Fosness, R.L., and Warren, J., 2016, Effects of dam removal on tule fall Chinook salmon spawning habitat in the White Salmon River, Washington: River Research and Applications, v. 32, p. 1481-1492.

Herrick, J.E., Schuman, G.E., and Rango, A., 2006, Monitoring ecological processes for restoration projects: Journal for Nature Conservation, v. 14, p. 161-171.

Inter-Fluve, 2013, Literature review of mainstem Columbia River anadromous salmonid habitat and restoration potential between Bonneville dam and the Yakima River Confluence: Inter-Fluve, Prepared for Mid-Columbia Fisheries Enhancement Group, White Salmon, Washington, 44 p.

Jolley, J.C., Silver, G.S., and Whitsel, T.A., 2013, Occurrence, detection, and habitat use of larval lamprey in the Lower White Salmon River and mouth:-Post-Condit Dam removal: U.S. Fish and Wildlife Service, Columbia River Fisheries Program Office, 2012 Annual Report, Vancouver, Washington, accessed December 13, 2016, at https://www.fws.gov/columbiariver/publications/White_Salmon_lamprey_Final.pdf.

Klickitat County, 2013, Klickitat lead entity region salmon recovery strategy, 2013: Klickitat County, Washington, 121 p., accessed April 26, 2017, at http://www.klickitatcounty.org/DocumentCenter/View/235.

Kondolf, G.M., Anderson, S., Lave, R., Pagano, L., Merelender, A., and Bernhardt, E.S., 2007, Two decades of river restoration in California-What can we learn?: Restoration Ecology, v. 15, p. 515523.

Lane and Lane Associates, 1981, White Salmon River Indian fisheries and Condit Dam: Portland, Oregon, Lane and Lane Associates with Douglas Nash, Prepared for Bureau of Indian Affairs.

Lower Columbia Fish Recovery Board, 2010a, Research, Monitoring and Evaluation Program for Lower Columbia Salmon and Steelhead: Lower Columbia Fish Recovery Board, 223 p., accessed November 28, 2016, at http://media.wix.com/ugd/810197_f87f5728a79b46ed9c508177e4ed4cf4.pdf.

Lower Columbia Fish Recovery Board, 2010b, Washington Lower Columbia Salmon Recovery and Fish and Wildlife Subbasin Plan: Lower Columbia Fish Recovery Board, 74 p., accessed November 28, 2016, at http://media.wix.com/ugd/810197_dec0786f0c474a1192fa14b45bde9be3.pdf.

McElhany, P., Ruckelshaus, M.H., Ford, M.J., Wainright, T.C., and Bjorkstedt, E.P., 2000, Viable salmonid populations and the recovery of evolutionarily significant units: U.S. Department of Commerce, NOAA Technical Memorandum National Marine Fisheries Service-NWFSC-42, 146 p. 
National Marine Fisheries Service, 2009, Middle Columbia River steelhead distinct population segment ESA Recovery Plan: Prepared by National Marine Fisheries Service Northwest Region, 260 p, accessed November 28, 2016, at http://www.westcoast.fisheries.noaa.gov/publications/recovery_planning/salmon_steelhead/domains/i nterior_columbia/middle_columbia/mid-c-plan.pdf.

National Marine Fisheries Service, 2013a, ESA Recovery Plan for Lower Columbia River coho salmon, Lower Columbia River Chinook salmon, Columbia River Chum salmon, and Lower Columbia River steelhead: Prepared by National Marine Fisheries Service Northwest Region, 503 p., accessed November 28, 2016, at http://www.westcoast.fisheries.noaa.gov/publications/recovery_planning/salmon_steelhead/domains/ willamette_lowercol/lower_columbia/final_plan_documents/final_lcr_plan_june_2013_corrected.pdf.

National Marine Fisheries Service, 2013b, ESA Recovery Plan for the White Salmon River Watershed: Prepared by National Marine Fisheries Service Northwest Region, 186 p., accessed November 28, 2016, at http://www.westcoast.fisheries.noaa.gov/publications/recovery_planning/salmon_steelhead/domains/ willamette_lowercol/lower_columbia/final_plan_documents/white_salmon_recovery_plan_june_201 3.pdf.

Northwest Power and Conservation Council, 2004, White Salmon Subbasin Plan: Portland, Oregon, Northwest Power and Conservation Council, 248 p., accessed December 12, 2016, at https://www.nwcouncil.org/media/116777/EntirePlan.pdf.

O’Connor, J.E., Duda, J.J., and Grant, G.E., 2015, 1000 dams down and counting: Science, v. 348, p. 496-497.

Pess, G., 2009, Patterns and processes of salmon colonization: Seattle, University of Washington, Ph.D Dissertation, $224 \mathrm{p}$.

Plummer, E., and Zuckerman, A., 2012, White Salmon River anadromous fish passage inventory 20092011 Survey Report: Underwood Conservation District Report, Prepared for Washington Salmon Recovery Funding Board, $53 \mathrm{p}$.

Reiser, D.W., Huang, C., Beck, S., Gagner, M., and Jeanes E., 2006, Defining flow windows for upstream passage of adult anadromous salmonids at cascades and falls: Transactions of the American Fisheries Society, v. 135, p. 668-679.

Smith, C.T., and Engle R., 2011, Persistent reproductive isolation between sympatric lineages of fall Chinook Salmon in White Salmon River, Washington: Transactions of the American Fisheries Society, v. 140, p. 699-715.

Temple, G.M., and Pearsons, T.N., 2007, Electrofishing-Backpack and drift boat, in Johnson, D.H., Shrier, B.M., O`Neal, J.S., Knutzen, J.A., Augerot, X., O'Neil, T.A., and Pearsons, T.N., eds., Salmonid field protocols handbook-Techniques for assessing status and trends in salmon and trout populations: Bethesda, Maryland, American Fisheries Society, p. 95-132.

Thedinga, J.F., Murphy, M.L., Johnson, S.W., Lorenz, J.M., and Koski, K.V., 1994, Determination of salmonid smolt yield with rotary-screw traps in the Situk River, Alaska, to predict effects of glacial flooding: North American Journal of Fisheries Management, v. 14, p. 837-851.

Tullos, D.D., Collins, M.J., Bellmore, J.R., Bountry, J.A., Connolly, P.J., Shafroth, P.B., and Wilcox, A.C., 2016, Synthesis of common management concerns associated with dam removal: Journal of the American Water Resources Association, v. 52, p. 1179-1206, doi: 10.1111/1752-1688.12450. 
Wilcox, A.C., O’Connor, J.E., and Major, J.J., 2014, Rapid reservoir erosion, hyperconcentrated flow, and downstream deposition triggered by breaching of $38 \mathrm{~m}$ tall Condit Dam, White Salmon River, Washington: Journal of Geophysical Research, Earth Surface, v. 119, p. 1376-1394, doi:10.1002/2013JF003073.

Volkhardt, G.C., Johnson, S.L., Miller, B.A., Nickelson, T.E., and Seiler, D.E. 2007, Rotary screw traps and inclined plane screen traps, in Johnson, D.H., Shrier, B.M., O’Neal, J.S., Knutzen, J.A., Augerot, X., O’Neal, T.A., and Pearsons, T.N., eds., Salmonid field protocols handbook-Techniques for assessing status and trends in salmon and trout populations: American Fisheries Society, p. 235-266.

Washington State Department of Ecology, 2016, Water quality standards for surface waters of the State of Washington-Chapter 173-201A WAC: Washington State Department of Ecology, 142 p., accessed April 26, 2017, at https://fortress.wa.gov/ecy/publications/documents/0610091.pdf.

Zendt, J., Romero, N., Keep, S., and Babcock, M., 2016, Klickitat subbasin monitoring and evaluationYakima/Klickitat Fisheries Project (YKFP): Bonneville Power Administration, Annual Report for 2013-2015, BPA Project Number 1995-063-35, accessed December 20, 2016, at https://www.cbfish.org/Document.mvc/Viewer/P148516. 


\section{Appendix A. Length Frequencies}

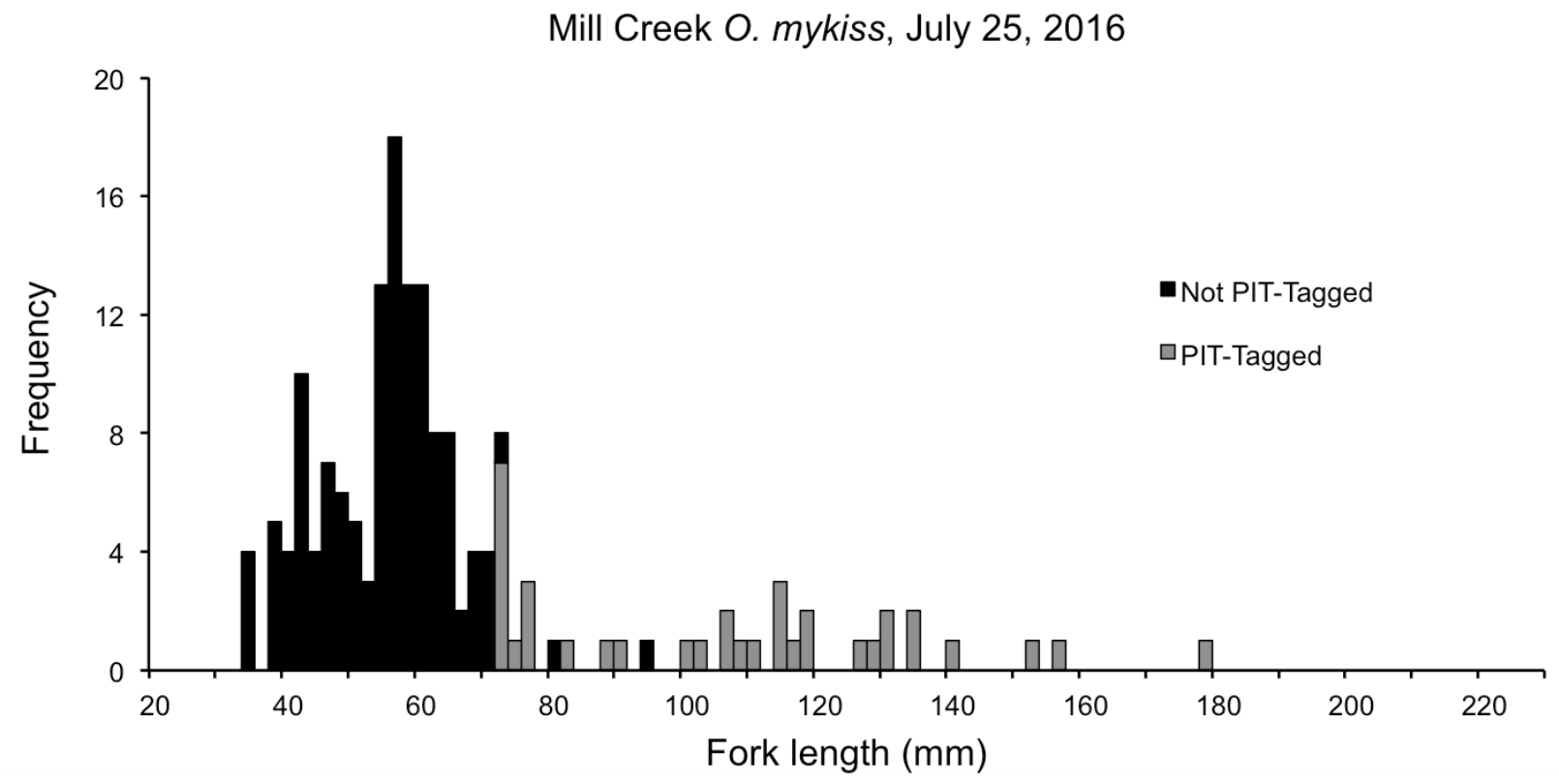

Mill Creek coho salmon, July 25, 2016

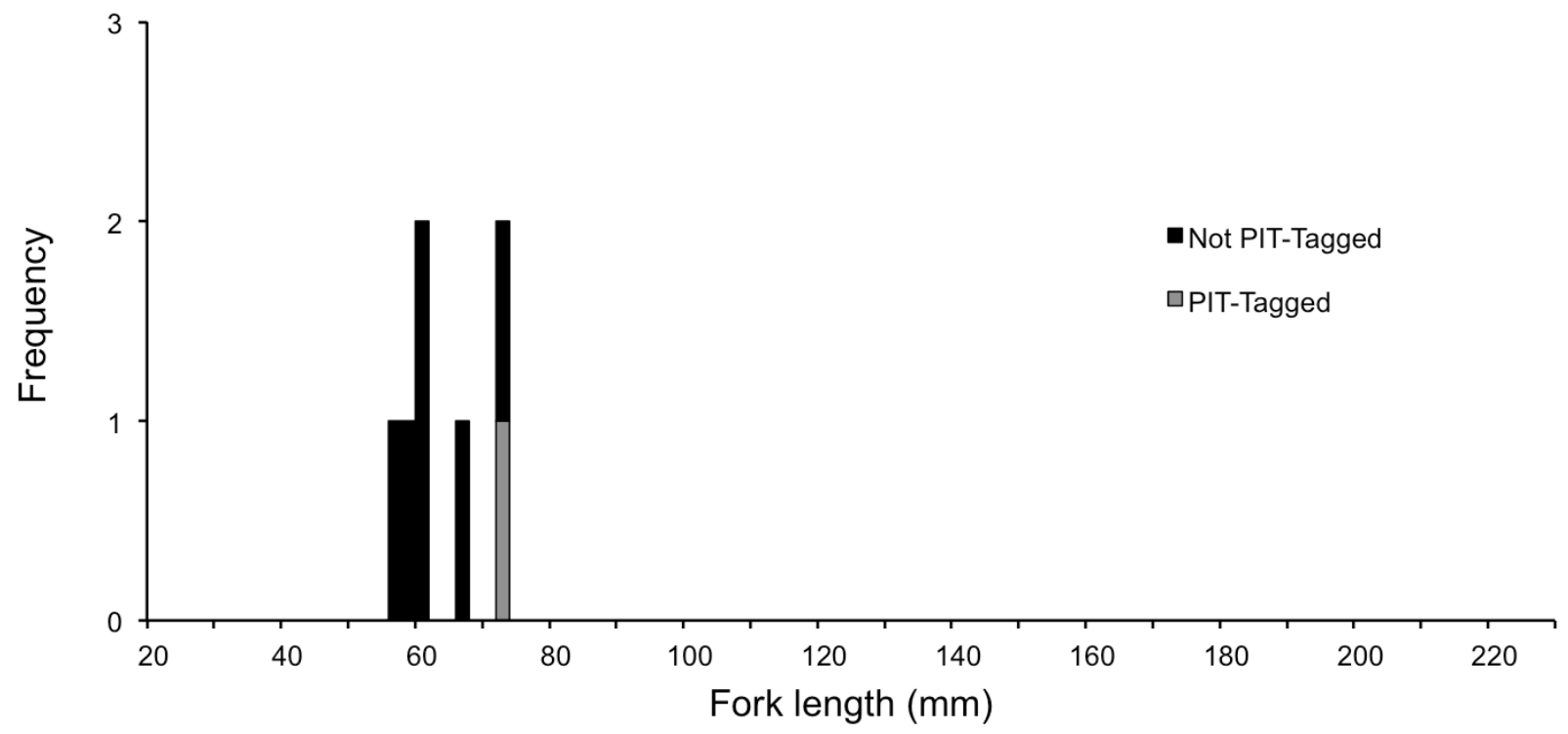

Figure A1. Graphs showing length frequency in 2-millimeter $(\mathrm{mm})$ increments of steelhead/rainbow trout (Oncorhynchus mykiss) and coho salmon (O. kisutch) sampled in the lower 250 meters of Mill Creek, Washington, 2016. (PIT, passive integrated transponder) 


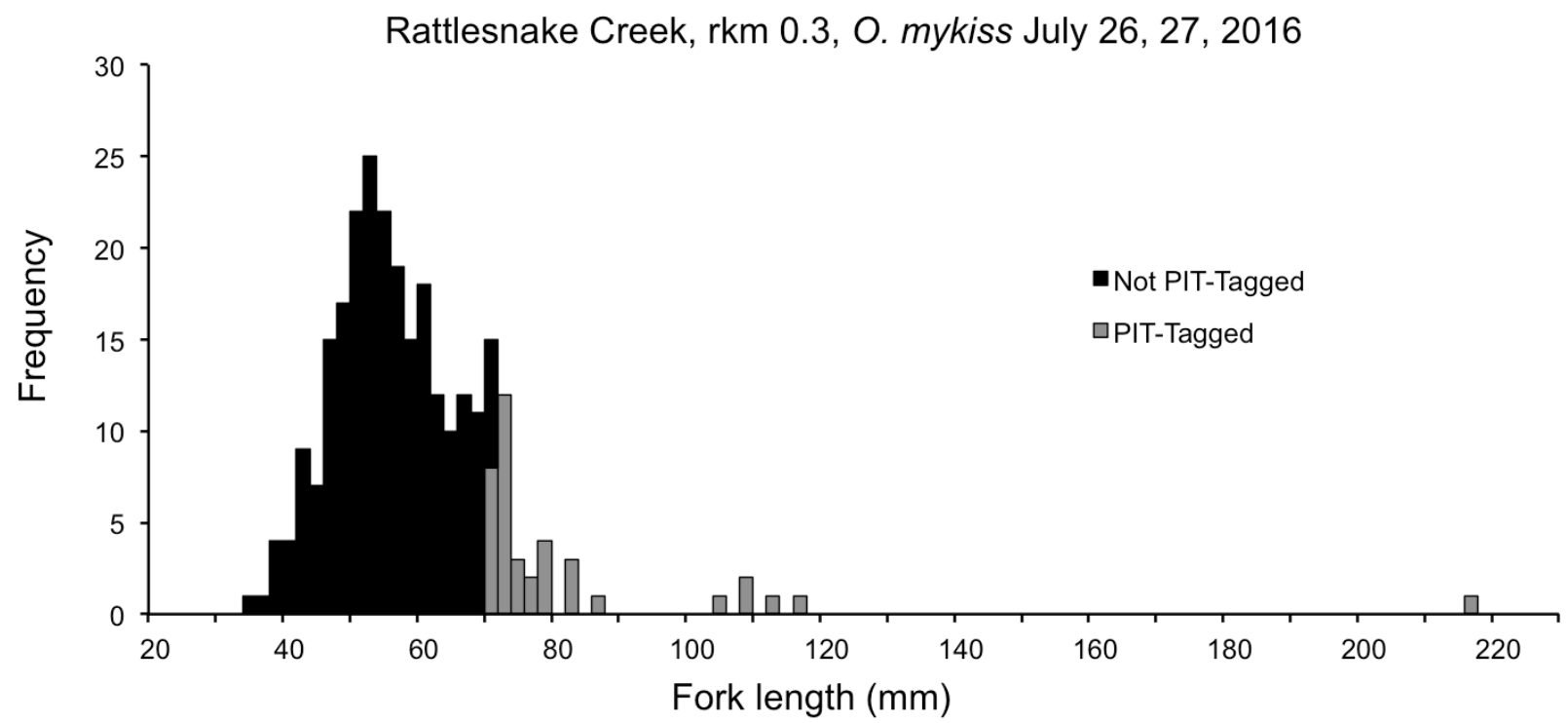

Figure A2. Graph showing length frequency in 2-millimeter $(\mathrm{mm})$ increments of steelhead/rainbow trout (Oncorhynchus mykiss) sampled in the lower kilometer of Rattlesnake Creek, Washington, 2016. (PIT, passive integrated transponder)

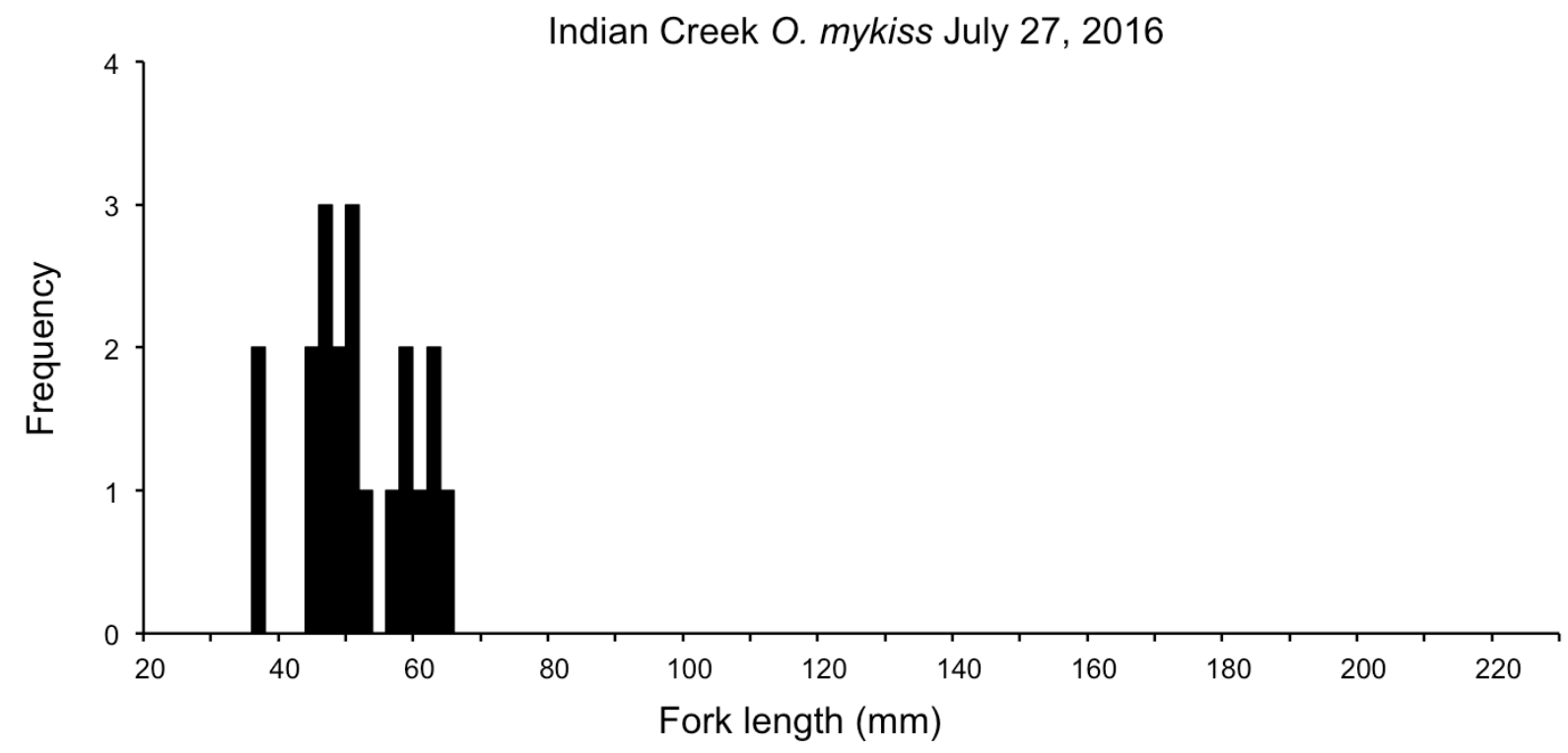

Figure A3. Graph showing length frequency in 2-millimeter $(\mathrm{mm})$ increments of steelhead/rainbow trout (Oncorhynchus mykiss) sampled in the lower 50 meters of Indian Creek, Washington, 2016. (PIT, passive integrated transponder) 


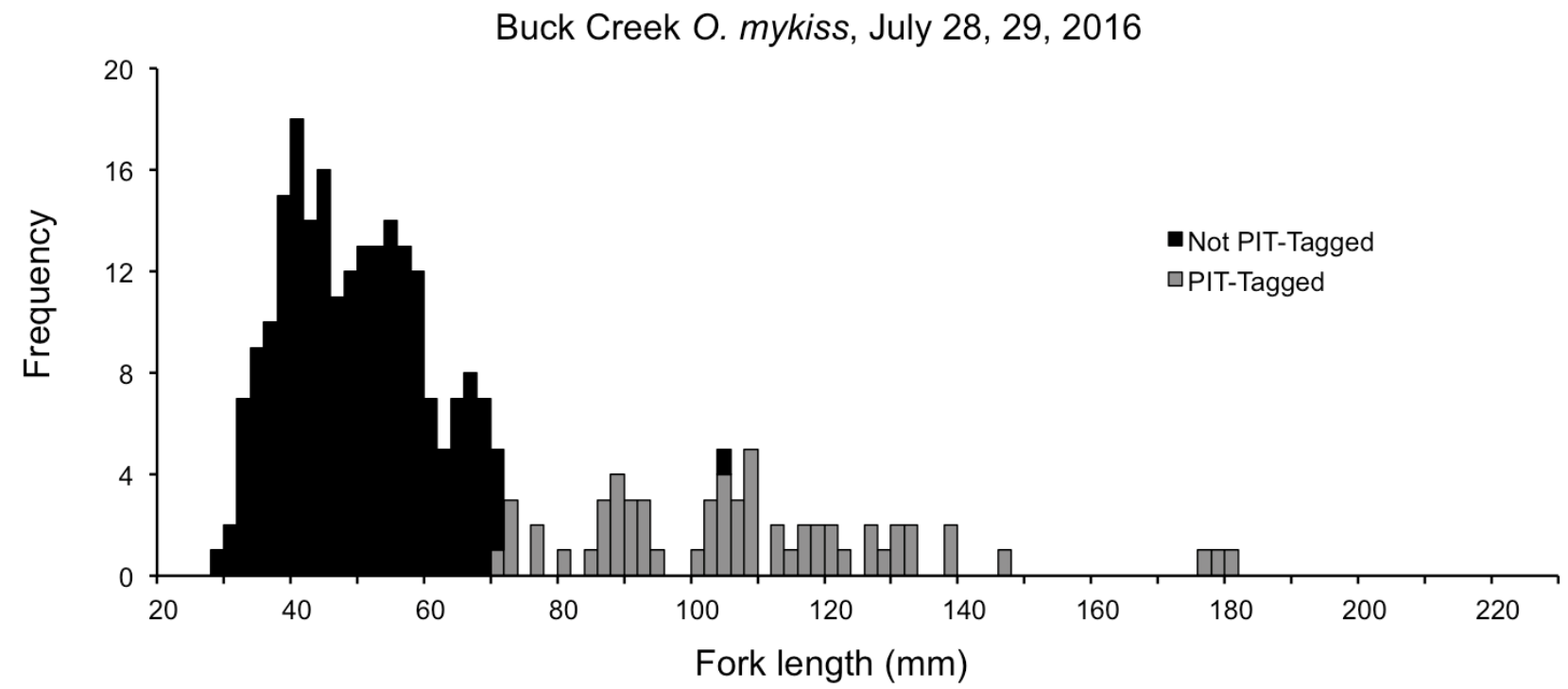

Figure A4. Graphs showing length frequency in 2-millimeter $(\mathrm{mm})$ increments of steelhead/rainbow trout (Oncorhynchus mykiss) and coho salmon (O. kisutch) sampled at river kilometer 2 of Buck Creek, Washington, 2016. (PIT, passive integrated transponder) 
White Salmon River, rkm 2.3, O. mykiss, August 2, 2016

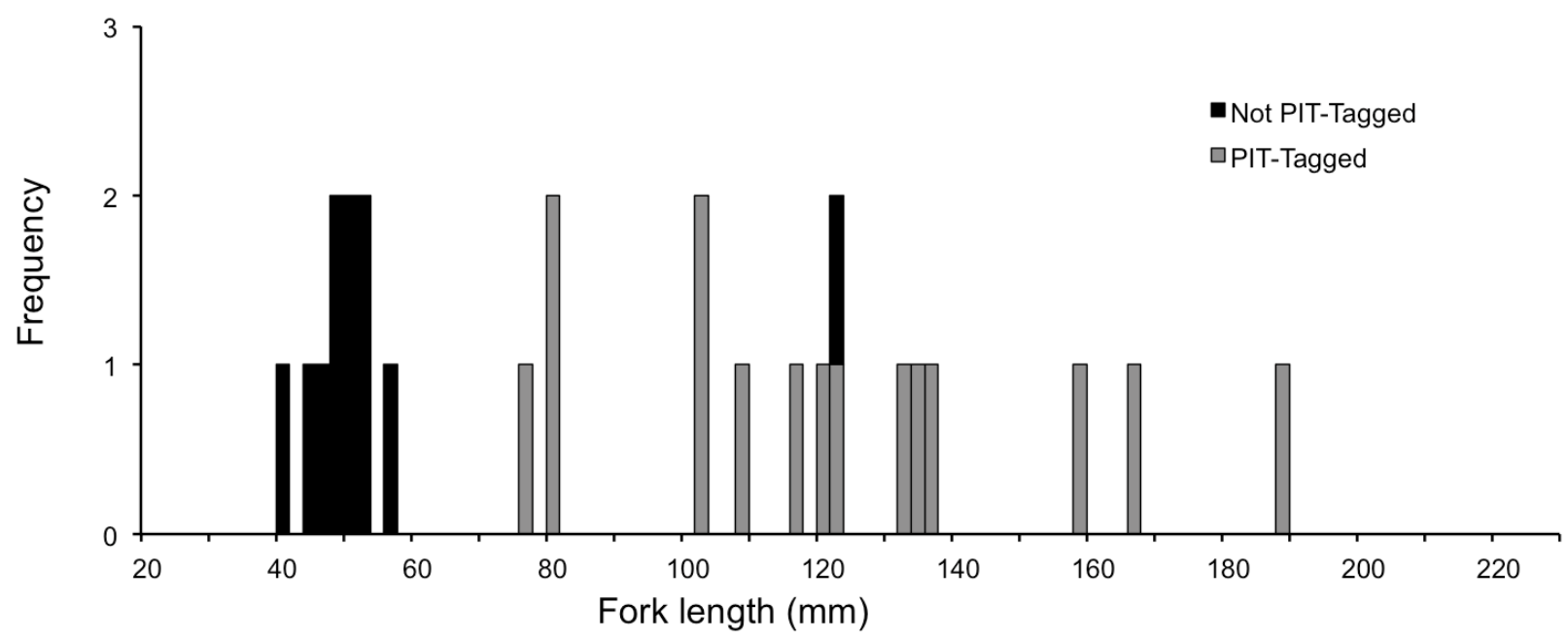

White Salmon River, rkm 12.3, O. mykiss, August 3, 2016

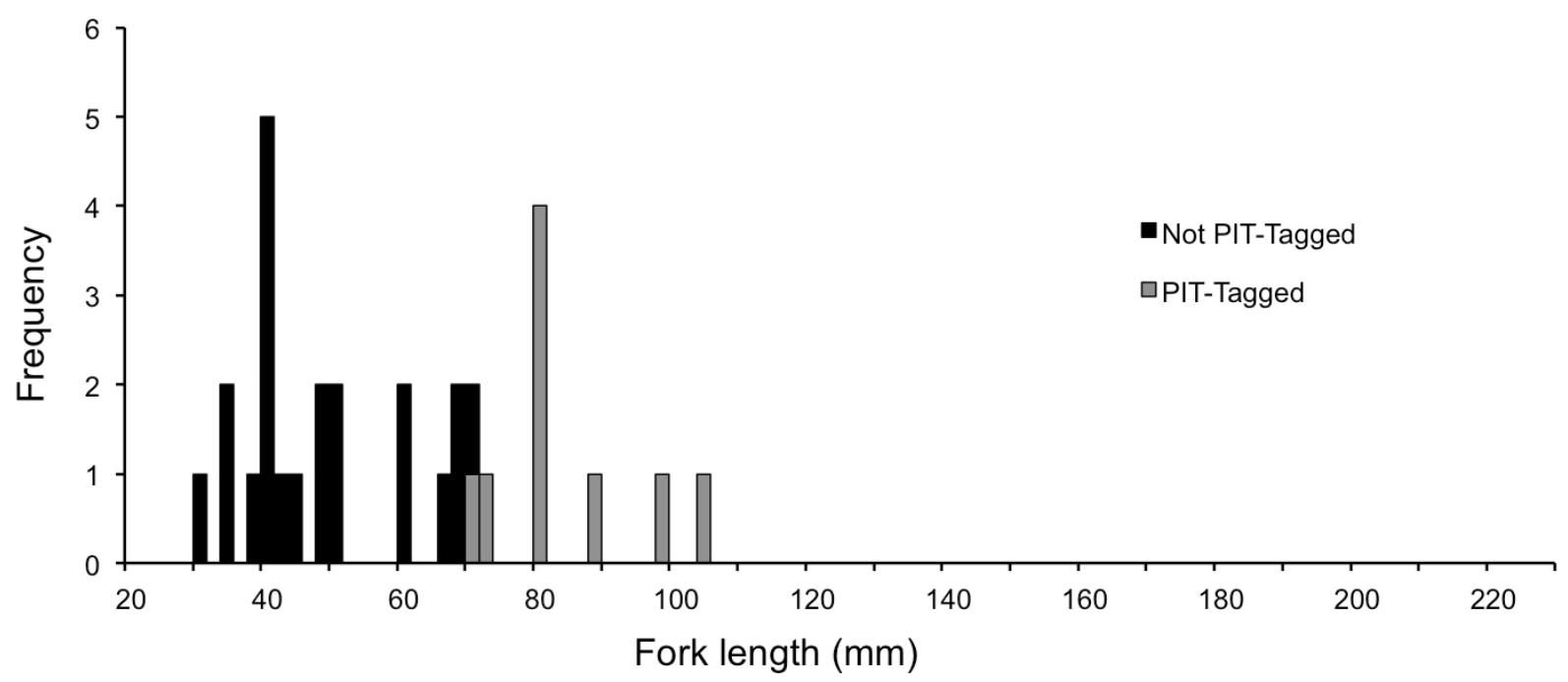

Figure A5. Graphs showing length frequency in 2-millimeter $(\mathrm{mm})$ increments of steelhead/rainbow trout (Oncorhynchus mykiss) sampled at two locations, White Salmon River, Washington, 2016. (PIT, passive integrated transponder) 
Mill Creek at rkm 0.5, O. mykiss, August 8, 2016

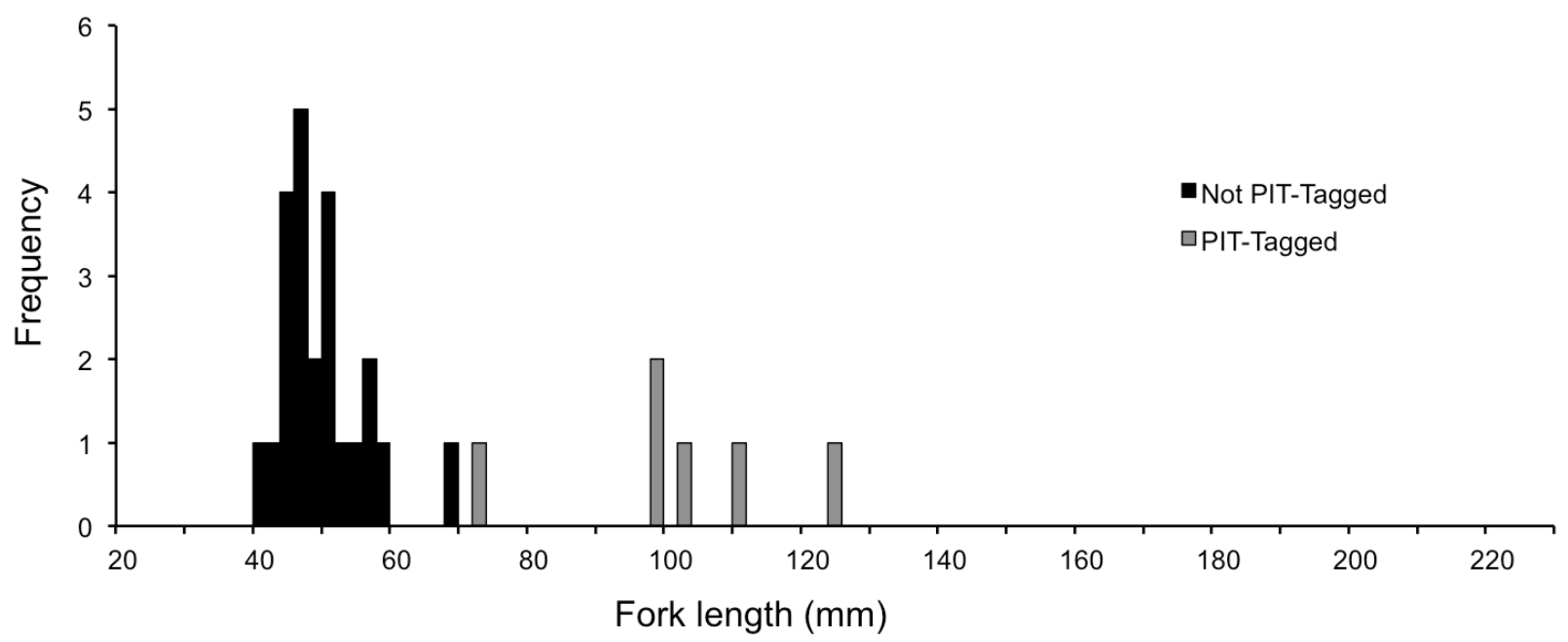

Mill Creek at rkm 0.5, coho salmon, August 8, 2016

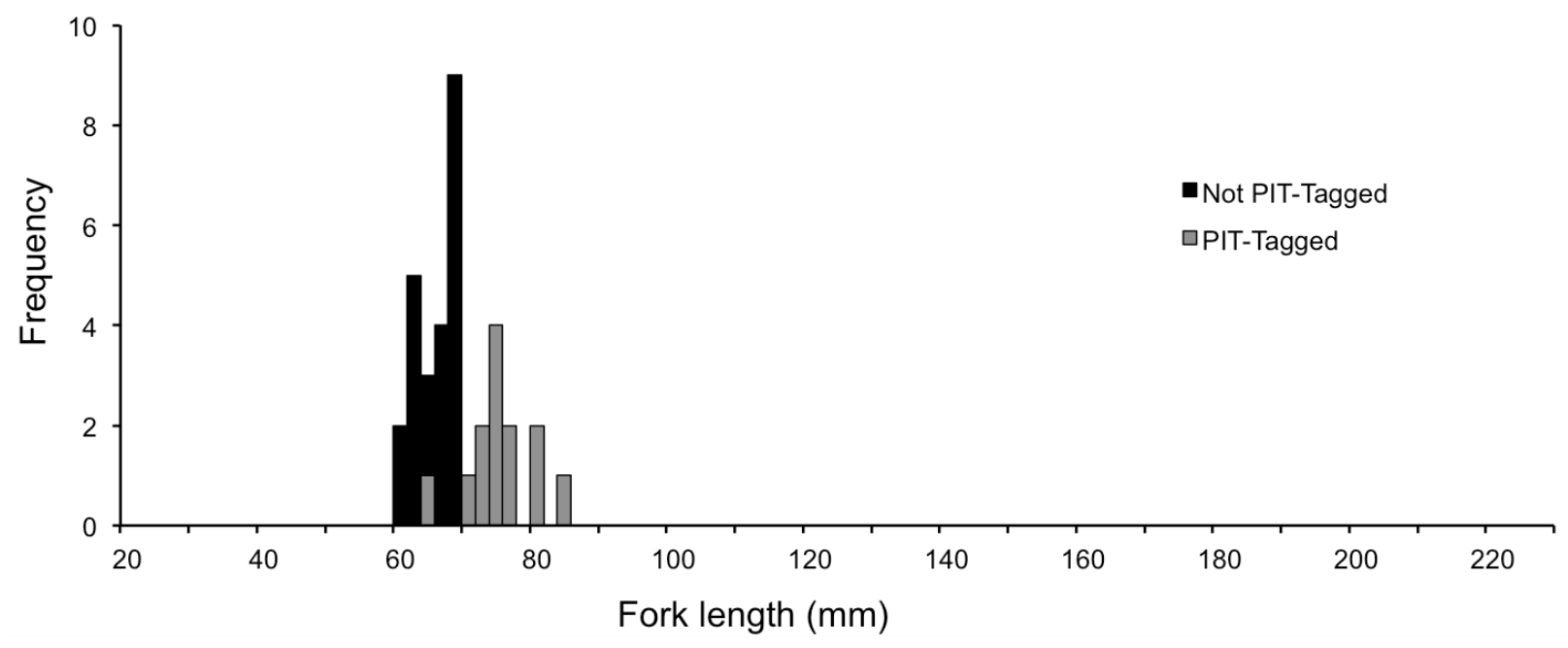

Figure A6. Graphs showing length frequency in 2-millimeter $(\mathrm{mm})$ increments of steelhead/rainbow trout (Oncorhynchus mykiss) and coho salmon (O. kisutch) sampled at river kilometer 0.5, Mill Creek, Washington, 2016. (PIT, passive integrated transponder) 


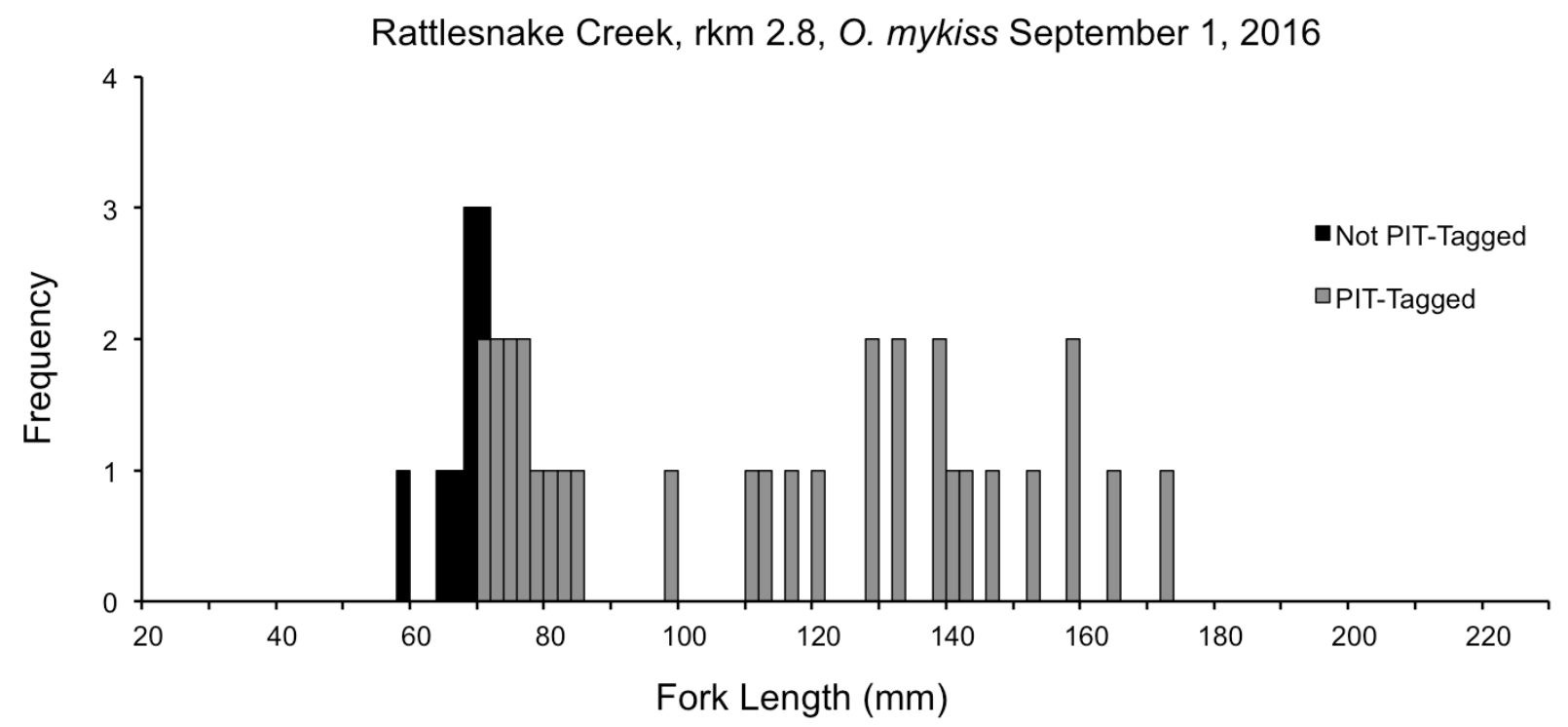

Figure A7. Graph showing length frequency in 2-millimeter $(\mathrm{mm})$ increments of steelhead/rainbow trout (Oncorhynchus mykiss) sampled at river kilometer 2.8, Rattlesnake Creek, Washington, 2016. (PIT, passive integrated transponder)



Figure A8. Graph showing length frequency in 2-millimeter $(\mathrm{mm})$ increments of steelhead/rainbow trout (Oncorhynchus mykiss) sampled at river kilometer 0.4, Rattlesnake Creek, Washington, 2016. (PIT, passive integrated transponder) 
Publishing support provided by the U.S. Geological Survey

Science Publishing Network, Tacoma Publishing Service Center

For more information concerning the research in this report, contact the Director, Western Fisheries Research Center

U.S. Geological Survey

6505 NE 65th Street

Seattle, Washington 98115

https://wfrc.usgs.gov/ 
